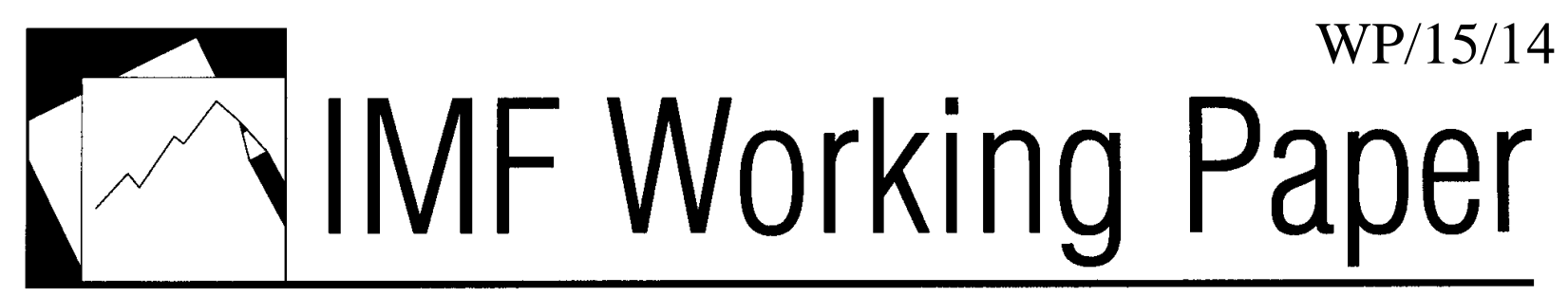

\title{
Output Gap Uncertainty and Real-Time Monetary Policy
}

Francesco Grigoli, Alexander Herman, Andrew Swiston, and Gabriel Di Bella 


\title{
IMF Working Paper
}

Western Hemisphere Department

\section{Output Gap Uncertainty and Real-Time Monetary Policy}

\section{Prepared by Francesco Grigoli, Alexander Herman, Andrew Swiston, and} Gabriel Di Bella ${ }^{1}$

Authorized for distribution by Przemek Gajdeczka

January 2015

\section{This Working Paper should not be reported as representing the views of the IMF.}

The views expressed in this Working Paper are those of the author(s) and do not necessarily represent those of the IMF or IMF policy. Working Papers describe research in progress by the author(s) and are published to elicit comments and to further debate.

\begin{abstract}
Output gap estimates are subject to a wide range of uncertainty owing to data revisions and the difficulty in distinguishing between cycle and trend in real time. This is important given the central role in monetary policy of assessments of economic activity relative to capacity. We show that country desks tend to overestimate economic slack, especially during recessions, and that uncertainty in initial output gap estimates persists several years. Only a small share of output gap revisions is predictable ex ante based on characteristics like output dynamics, data quality, and policy frameworks. We also show that for a group of Latin American inflation targeters the prescriptions from typical monetary policy rules are subject to large changes due to output gap revisions. These revisions explain a sizable proportion of the deviation of inflation from target, suggesting this information is not accounted for in realtime policy decisions.
\end{abstract}

JEL Classification Numbers: E01, E32, E43, E52

Keywords: Output gap; monetary policy; policy rule; data revisions; real-time; uncertainty; Brazil; Chile; Colombia; Mexico; Peru; inflation target; business cycle.

Authors’ E-Mail Addresses: fgrigoli@imf.org; aherman@imf.org; aswiston@imf.org; gdibella@imf.org

\footnotetext{
${ }^{1}$ We would like to thank Tamim Bayoumi, Patrick Blagrave, Alexander Culiuc, Valerie Cerra, Ana Corbacho, Ernesto Crivelli, Przemek Gajdeczka, Roberto Garcia-Saltos, Huidan Lin, Luca Ricci, Alejandro Werner, Aleksandra Zdzienicka, and participants of the Western Hemisphere Department Seminars held in August and September 2014 for helpful comments and suggestions.
} 


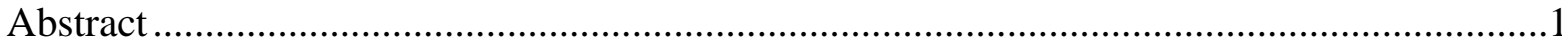

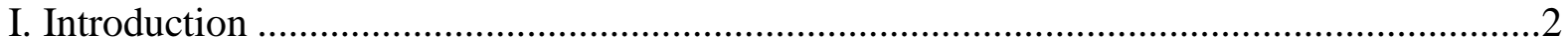

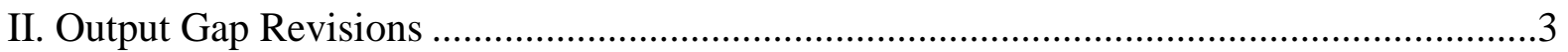

A. Output Gap Definition and Data ...............................................................

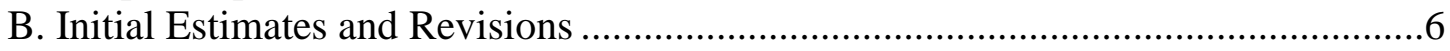

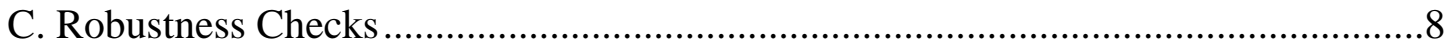

III. Determinants of Output Gap Revisions .................................................................. 11

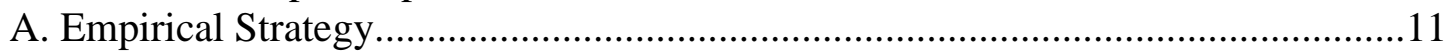

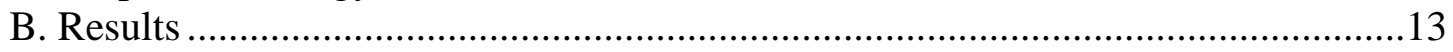

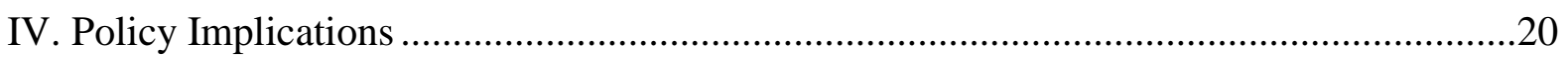

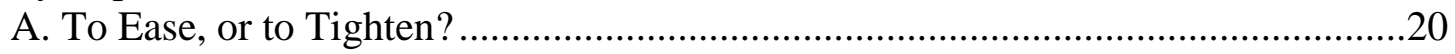

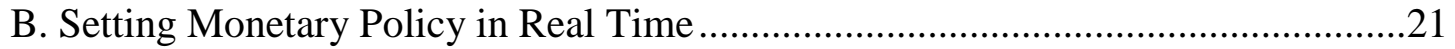

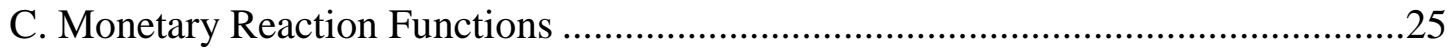

D. Output Gap Revisions and Policy Revisions ..................................................26

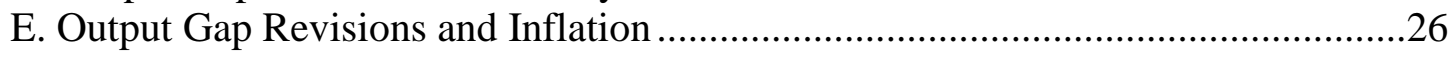

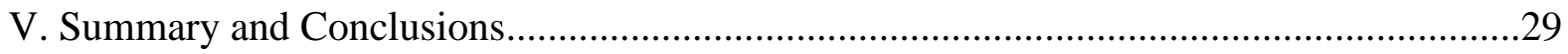

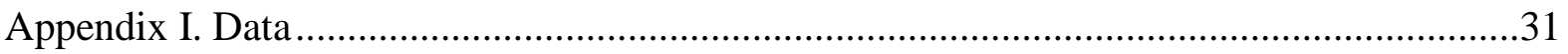

Tables

1. Sources of Revisions to Output Gap Estimates .............................................................4

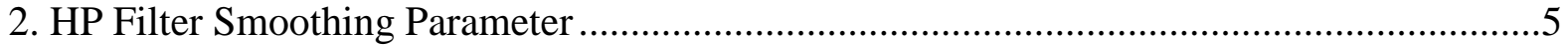

3. Output Gap: Initial Estimates and Revisions .............................................................

4. Determinants of the Absolute Revisions of the Output Gap, Baseline ..............................14

5. Determinants of the Absolute Revisions of the Output Gap, Extensions ...........................17

6. Determinants of the Probability of the Output Gap Changing Sign .................................19

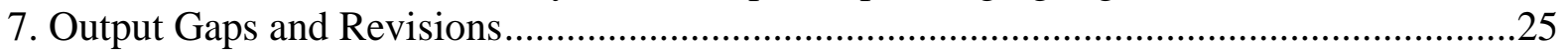

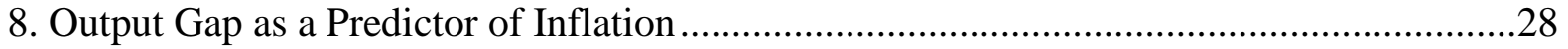

Figures

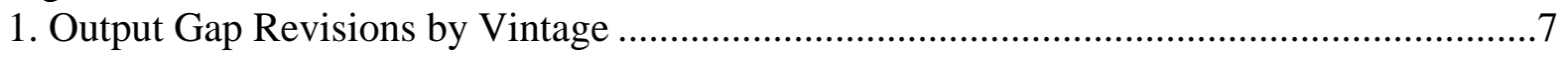

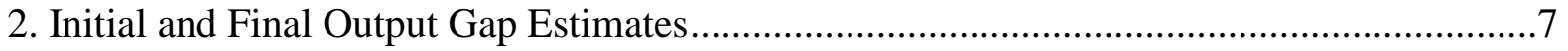

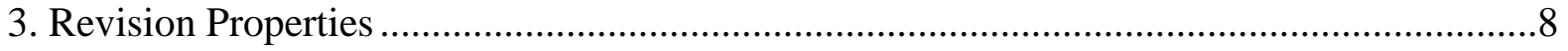

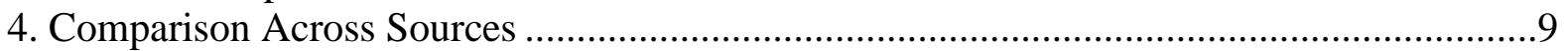

5. Comparison Across US Output Gap Estimates ...............................................................10

6. Real-Time Output Gap Estimates and Confidence Intervals .........................................21

7. Quarterly Output Gap estimates for LA-5 Economies ...............................................24

8. Policy Deviations Owing to Output Gap Revisions .....................................................27

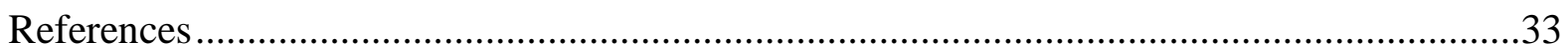


"What is it that no one can see, hear, smell, taste or touch, yet everyone knows is there? Answer: the output gap." Caroline Baum, Bloomberg, April 12, 2010

\section{INTRODUCTION}

Reliable output gap measures are essential for policymaking. Both fiscal and monetary policy reaction functions use output gap estimates as an input in assessing the appropriate settings for relevant instruments (e.g., the structural fiscal balance or the interest rate). While fiscal and monetary authorities analyze a wide variety of indicators in assessing the cyclical position of the economy (including deviations of unemployment from its natural rate), they frequently resort to the output gap to summarize their assessment of economy-wide spare capacity.

Despite being widely used in policymaking, initial output gap estimates are characterized by large uncertainty. This has been extensively documented in the literature. For instance, Orphanides and van Norden (2002) show how real-time estimates of the U.S. output gap have often proven highly inaccurate. Ley and Misch (2013) highlight this phenomenon across a broad range of countries. In a somewhat related fashion, Ho and Mauro (2014) find that long-term growth forecasts suffer from "optimism bias", in particular for countries whose recent growth has been below trend. Uncertainty as to the position of the economy in the cycle was particularly important at the time of the global financial crisis. For instance the size of the output gap in the United States has been repeatedly reassessed after 2007, given the large uncertainty on the impact of the financial crisis on potential output (IMF, 2010). Needless to say, this uncertainty has important policy implications and can lead to difficulties in setting a policy that is appropriate given the true state of the economy. This topic has become particularly important for emerging markets, including many in Latin America. This is the case as, during the last decade, many of these countries have transitioned toward rulebased monetary policy frameworks.

This paper revisits the issue of output gap uncertainty by analyzing properties and determinants of real-time output gap estimates from different sources for the period 19902014. It focuses on the changes in output gap estimates that arise due to ex-post GDP data revisions and changes in the decomposition of actual GDP data into its cyclical and trend components. It empirically assesses whether real-time data can predict how much the output gap will be revised later. The paper then analyzes the implications of output gap uncertainty for five Latin American economies that have implemented inflation targeting over the last decade. Our results suggest that country desks tend to overstate economic slack. In addition, we show that revisions are substantial (especially during recessions), persistent, and, to a large extent, unpredictable. Finally, we find that revisions help to explain deviations of inflation from the target, suggesting that this information is not accounted for in real-time policy decisions. 
The paper is organized as follows. Section II examines the statistical properties of output gap estimates and their revisions in order to quantify the uncertainty that surrounds initial estimates of the output gap. Section III looks at whether these revisions can be predicted based either on country-specific characteristics or the country's position in the business cycle at the time of the initial estimate. Section IV illustrates the policy implications of output gap uncertainty on five Latin American economies that have operated with inflation targeting schemes during the last decade. Section V concludes.

\section{OUtPut GAP ReVisions}

This section examines the statistical properties of output gap estimates and their revisions, in order to evaluate the degree of confidence that can be attached to initial assessments of an economy's cyclical position.

\section{A. Output Gap Definition and Data}

The output gap is an unobserved, estimated concept, and therefore not known with certainty. It is defined as the deviation of actual from potential output, as a percent of potential. In equation (1) below, $y$ denotes actual output (measured by real GDP) and $y^{*}$ represents potential output, which is defined as the output an economy could produce if all factors of production were operating at their full employment rates of capacity. The output gap is denoted by $\bar{y}$ :

$\bar{y}=\frac{\left(y-y^{*}\right)}{y^{*}} * 100$

A negative (positive) sign for the output gap indicates that output is below (above) potential. Estimates of potential output are heavily influenced by the average level of an economy's production over time. Revisions to the initial estimate of the output gap could occur as subsequent developments change estimates of the economy's productive capacity in previous periods.

Table 1 shows the possible sources of deviations of initial estimates of the output gap compared to their final estimates. Let $t$ denote the period under analysis. Estimates made before or during year $t$ are forecasts. The first estimate in which data for year $t$ is known is called the initial estimate, and subsequent estimates until the final estimate are called revised estimates. ${ }^{2}$ Evaluating revisions to initial estimates requires a decision on which subsequent vintage will serve as the final estimate. This paper uses as the final estimate the estimated output gap seven years after the period in question, as revisions typically level off within seven years. This picks up revisions to the output gap at business cycle frequencies.

\footnotetext{
${ }^{2}$ An annual frequency is assumed but the principles translate to any frequency.
} 
As shown in Table 1, deviations between the forecast and final estimate of the output gap can come from four possible sources. The first is that the forecast serves as an input into the policymaker's reaction function. If policymakers base their decisions in part on the forecast and policy affects output within the year, it is to be expected that the outturn will differ from the forecast. A second source of uncertainty is forecast error; factors other than policy could cause the realized output gap to differ from the forecast, and even if policy is implemented as projected, its effects could differ from what was forecast.

Table 1. Sources of Revisions to Output Gap Estimates

\begin{tabular}{lll}
\hline Vintage of estimate & Descriptor & \multicolumn{1}{c}{ Possible sources of deviations from final } \\
\hline$t$ & Forecast & $\begin{array}{l}\text { Policy reactions, forecast error, data revisions, } \\
\text { uncertainty over potential output }\end{array}$ \\
\hline$t+1$ & $\begin{array}{l}\text { Initial } \\
\text { estimate }\end{array}$ & Data revisions, uncertainty over potential output \\
\hline$t+2 \ldots t+6$ & $\begin{array}{l}\text { Revised } \\
\text { estimates }\end{array}$ & Data revisions, uncertainty over potential output \\
\hline$t+7$ & $\begin{array}{l}\text { Final } \\
\text { estimate }\end{array}$ & None, by definition \\
\hline
\end{tabular}

This paper focuses on the third and fourth sources-revisions to the output gap arising from data revisions and those arising from changing the decomposition of actual data into its cyclical and trend components. These sources are present in forecasts and in all ex-post estimates until the final estimate, as data are revised and estimates of potential output take into account both data revisions for period $t$ and developments in subsequent periods.

This study will be restricted entirely to ex-post estimates - those made after data for the period under study has been released - in order to isolate the impact of data revisions and potential output uncertainty and ensure that deviations related to policy reactions and forecast error do not affect the findings. Modeling the real-time impact of policy reactions and deviations arising from forecast errors are outside the scope of the analysis.

This paper uses data and forecasts from the International Monetary Fund's (IMF) World Economic Outlook (WEO), released twice a year (in the spring and the fall). The WEO database consists of macroeconomic data and forecasts submitted by country teams and vetted by the IMF's Research Department for both internal and multilateral consistency.

Given the importance of working only with ex-post estimates, the vintage from which to draw the data is critical. The spring WEO was released in May up through 2001 and in April thereafter; the fall version is typically released in October, and occasionally in September. Given the production lags, forecasts for the spring publication are performed during February or March. Given this timeline, in the spring WEO real GDP data for the previous year will 
continue to be an estimate or forecast for some countries. For this reason, the analysis is performed with the fall vintages.

Data are available since 1991. Given that the final estimate of the output gap is that measured seven years after the period in question, the available WEO vintages allow the calculation of initial estimates and subsequent revisions up to the final estimate from 1990 to 2007. The WEO database contains real-time estimates of the output gap made by country desks for many advanced economies throughout this period. Estimates for many other economies, however, begin only in 2008. There is no prescribed estimation methodology, but the estimates are used by the IMF in discussions with country authorities over appropriate economic policies, underscoring the importance of an accurate assessment.

In order to cover as many countries as possible, we estimate output gaps using potential GDP obtained by applying the Hodrick-Prescott (HP) filter on real GDP data from the WEO and compare with the estimates from country desks where available. As shown in Table 2, we formally test which size of the smoothing parameter $\lambda$ commonly used for annual data (100 and 6.25) better fits the estimates provided in the WEO and in the OECD's Economic Outlook databases by regressing both filtered series on the WEO and OECD data. ${ }^{3}$ Table 3 reports the root mean squared errors (RMSE) and R-squared values below, suggesting that $\lambda$ set to 100 is a better analog of both WEO and OECD data. This suggests that country desks tend to interpret changes in real GDP as changes in cycle rather than in trend. Thus, in the analysis that follows we use HP-filtered data with $\lambda$ set to 100 for all countries while performing robustness checks on the results using the desk-provided estimates and HPfiltered data with $\lambda$ set to $6.25 .^{4}$ The baseline dataset has an average sample size of 176 countries per year, for a total of 3,018 observations.

Table 2. HP Filter Smoothing Parameter

\begin{tabular}{|c|c|c|c|c|}
\hline & \multicolumn{2}{|c|}{ RMSE } & \multicolumn{2}{|c|}{ R-squared } \\
\hline & HP filtered & EO data & HP filtered & EO data \\
\hline & $(\lambda=100)$ & $(\lambda=6.25)$ & $(\lambda=100)$ & $(\lambda=6.25)$ \\
\hline Observed WEO data & 2.11 & 2.25 & 0.47 & 0.40 \\
\hline Observed OECD data & 1.10 & 1.47 & 0.72 & 0.51 \\
\hline
\end{tabular}

Source: Authors' calculations.

\footnotetext{
${ }^{3}$ As noted in Baxter and King (1995), setting $\lambda$ to 10 or below closely replicates the statistical properties of the Baxter-King filter.

${ }^{4}$ We run the HP filter over all available historical data plus the forecast available in the WEO database to mitigate endpoint problems.
} 


\section{B. Initial Estimates and Revisions}

Initial assessments of an economy's cyclical position are subject to a high degree of uncertainty. Table 3 shows that revisions to the output gap are of the same order of magnitude as the initial estimates of the output gap itself, and that about one-third of economies have an output gap that changes signs between the initial and final estimates. Countries are divided into three groups to evaluate whether there are differences across types of country. Advanced economies include all OECD members as of 1990 (the beginning of the sample). Low-income economies include any country with a GNI per capita of $\$ 1,045$ or less in 2012. Emerging economies are all those that are not included in the other two groups. ${ }^{5}$ Revisions for emerging and low-income economies are larger than those for advanced economies and the estimates are more likely to switch signs. All these features of the data confirm the findings of Ley and Misch (2013).

Table 3. Output Gap: Initial Estimates and Revisions

(Percent of potential GDP)

\begin{tabular}{|c|c|c|c|c|c|c|c|c|}
\hline & \multirow{2}{*}{$\begin{array}{c}\text { Number } \\
\text { of } \\
\text { countries }\end{array}$} & \multicolumn{2}{|c|}{ Initial es timate } & \multicolumn{2}{|c|}{ Final estimate } & \multicolumn{2}{|c|}{ Revision } & \multirow{2}{*}{$\begin{array}{l}\text { Percent } \\
\text { switching } \\
\text { signs }\end{array}$} \\
\hline & & Median & $\begin{array}{l}\text { Standard } \\
\text { deviation }\end{array}$ & Median & $\begin{array}{l}\text { Standard } \\
\text { deviation }\end{array}$ & Median & $\begin{array}{l}\text { Standard } \\
\text { deviation }\end{array}$ & \\
\hline All countries & 176 & -0.97 & 5.12 & -0.22 & 5.57 & 0.75 & 3.89 & 32.3 \\
\hline Advanced & 24 & -0.24 & 1.61 & 0.27 & 2.49 & 0.51 & 1.67 & 22.9 \\
\hline Emerging & 122 & -0.98 & 5.47 & -0.34 & 5.90 & 0.64 & 4.11 & 32.7 \\
\hline Low-income & 30 & -1.77 & 5.28 & -0.22 & 5.93 & 1.55 & 4.16 & 38.8 \\
\hline
\end{tabular}

Source: Authors' calculations.

Uncertainty over the output gap persists for several years after the period under analysis. Figure 1 shows the absolute value of marginal output gap revisions in each vintage and at various percentiles. In the year following the initial estimate, the output gap of the typical country is revised by 0.9 percentage points. Two years later, the absolute value of the median revision remains nearly half a percentage point. Seven years after the year under analysis, a quarter of all countries experience revisions of half a percentage point and ten percent of all countries experience an output gap revision of a full percentage point.

In addition, initial assessments of the cyclical position overestimate the amount of slack in the economy. Actual output is 1.0 percent below potential output in initial estimates, but only 0.2 percent below potential in final estimates, and median revisions to the output gap exceed 0.5 percent of potential for all types of countries (Table 1; Figure 2, left panel). We call this phenomenon "excess capacity bias."

\footnotetext{
${ }^{5}$ See Appendix I for a complete list of countries in each group.
} 
Figure 1. Marginal Output Gap Revisions by Vintage

(Absolute value; percent of potential GDP)

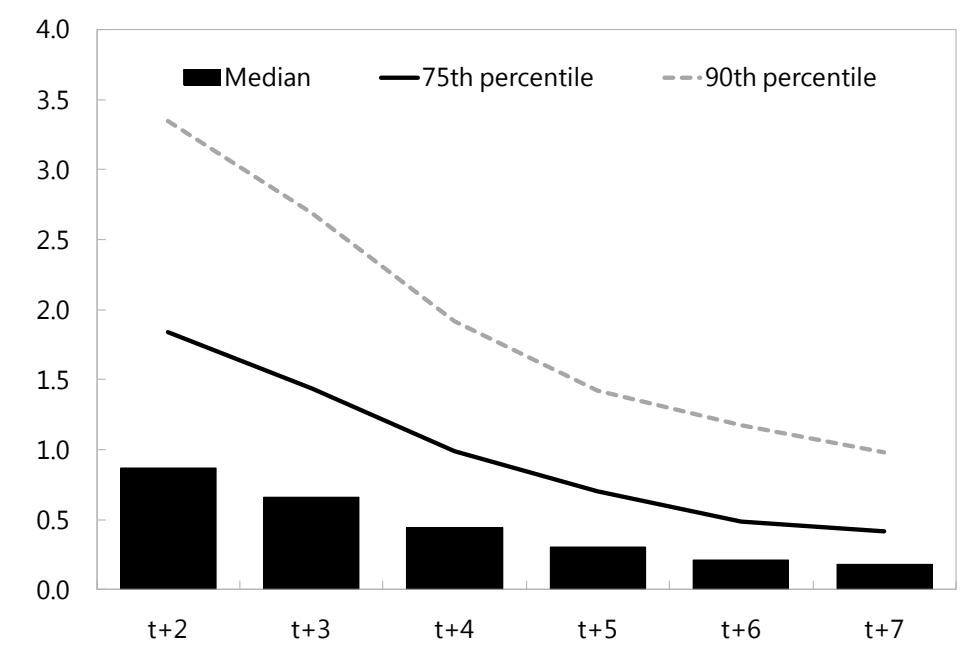

Source: Authors' calculations.

Two factors interact to produce excess capacity bias. First, initial estimates of economic activity tended to be revised upward in later vintages (Figure 2, middle panel). This fact by itself would not lead to a bias towards excess capacity, as persistent upward data revisions would tend to raise both actual and potential output without a substantial impact on the estimated cyclical position. However, economic activity tended to underperform IMF forecasts, in line with the findings of Ho and Mauro (2014) and Timmermann (2007). This second factor worked to keep cumulative revisions to estimated potential growth roughly neutral, at less than 0.1 percent of potential output, on average (Figure 2, right panel). The combination of upward revisions to past activity and downward revisions to current activity (relative to the forecast) results in the lower level of excess capacity in final estimates compared to initial estimates.

Figure 2. Initial and Final Output Gap Estimates
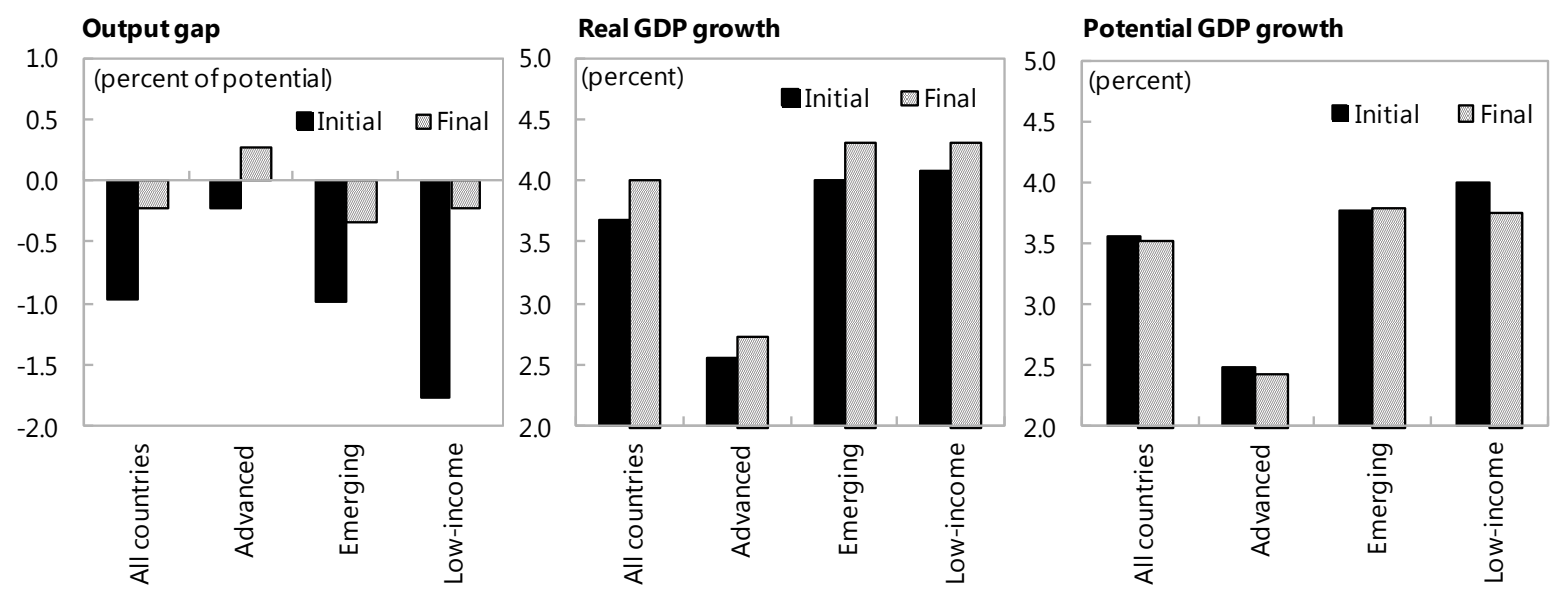

Source: Authors' calculations. 
Initial assessments of an economy's cyclical position are least reliable during recessions. Figure 3 compares the full sample and a subsample restricted to episodes in which the initial estimate of real GDP growth was negative, displaying for each group of observations the average absolute revision and the standard deviation of revisions. ${ }^{6}$ It shows that absolute revisions to the output gap, actual growth, and potential growth are 30 to 50 percent larger during downturns than in normal times, and the wider distribution of revisions - 30 percent higher than in the full sample-highlights the additional uncertainty over the cyclical position of an economy when growth is negative.

Figure 3. Revision Properties

(Cumulative revisions, final estimate minus initial estimate)
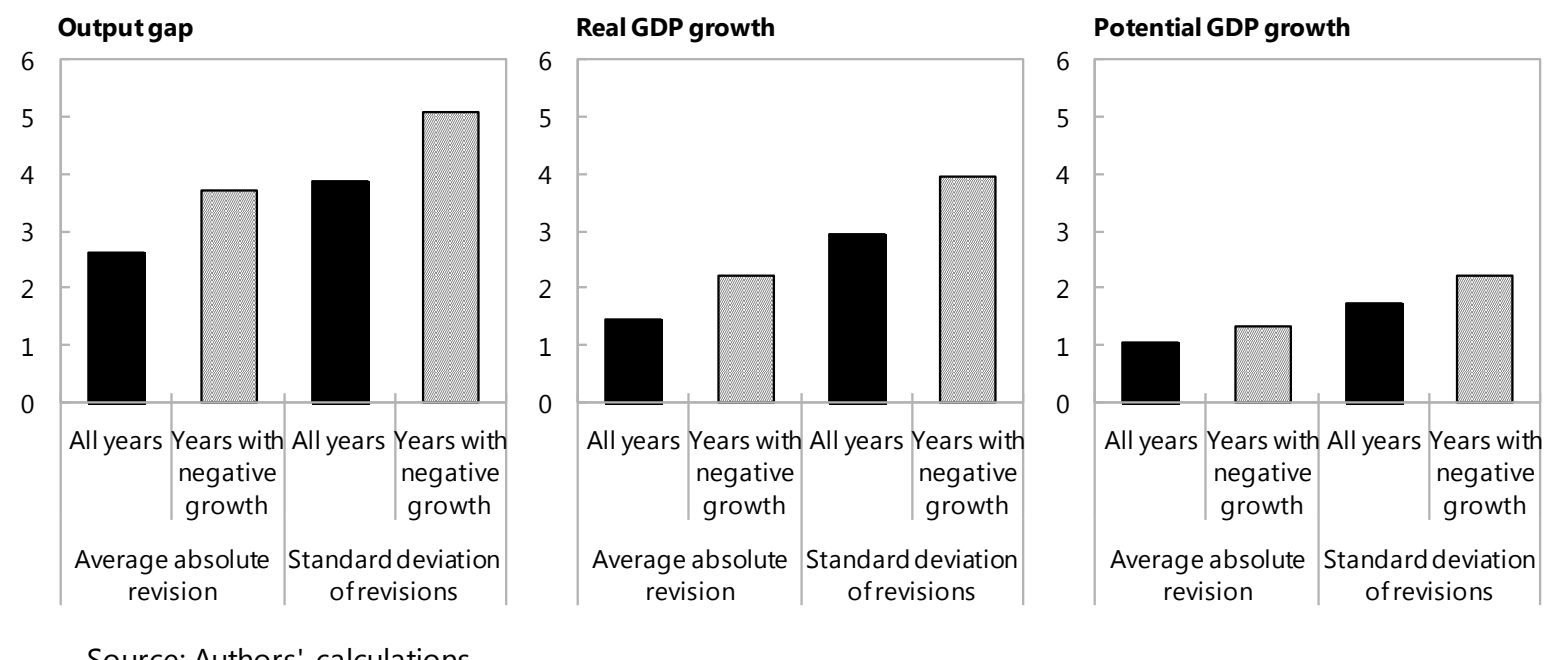

Source: Authors' calculations.

\section{Robustness Checks}

The key features of initial assessments of an economy's cyclical position and its subsequent revisions are 1) a high degree of uncertainty that persists several years beyond the period under analysis; 2) initial estimates have an excess capacity bias, overestimating the amount of spare capacity in an economy; and 3) increased uncertainty around cyclical turning points, in particular during economic downturns.

In order to ensure that these features of the data are not unique to the WEO dataset or our use of the HP filter to estimate potential output and the output gap, we perform several robustness checks.

\footnotetext{
${ }^{6}$ Clearly, turning points marking an acceleration of an economy could also be analyzed. Given that potential growth rates differ across economies, negative real GDP growth (especially at the annual frequency) may not catch all cyclical turning points, but it is probable that most observations in this subsample are turning points (with the most likely exception being economies in an extended period of negative growth). The results hold when negative growth is defined using the final estimate rather than the initial estimate.
} 
First, we use HP-filtered data generated by setting $\lambda$ equal to $6.25 .^{7}$ The median revisions are much lower than those when $\lambda$ is set to 100 , suggesting that the excess capacity bias depends on the parameter $\lambda$, and therefore on the extent to which real growth fluctuations are interpreted as structural. However, the ratios of standard deviations to medians are dramatically larger. This suggests that using $\lambda$ set to 6.25 creates higher levels of normalized volatility in output gap measurements and more evenly dispersed revisions across zero, implying an even higher uncertainty about the direction of the revision.

Second, we use estimates of the output gap from two cross-country sources: the OECD's Economic Outlook database and the WEO database. The December edition of the Economic Outlook was used, as its release coincides most closely with the Fall WEO. As with the WEO estimates, the OECD estimates are submitted directly by country teams using their own judgment as to the amount of spare capacity in each economy. Using estimates that rely on the judgment of analysts covering the economies in question should reveal whether the use of the HP filter is driving the results.

Both the WEO and OECD data cover mostly advanced economies, so Figure 4 compares the key metrics presented above with the HP-filtered estimates, all using the same sample of advanced economies (see Appendix I). Country desks' estimates display at least as much persistent uncertainty in revisions and excess capacity bias as the HP-filtered estimates. In fact, the right panel in Figure 4 shows that the typical revisions from these sources are larger and more variable than those from the HP-filtered data.

Figure 4. Comparison Across Sources

(Data for advanced economies)

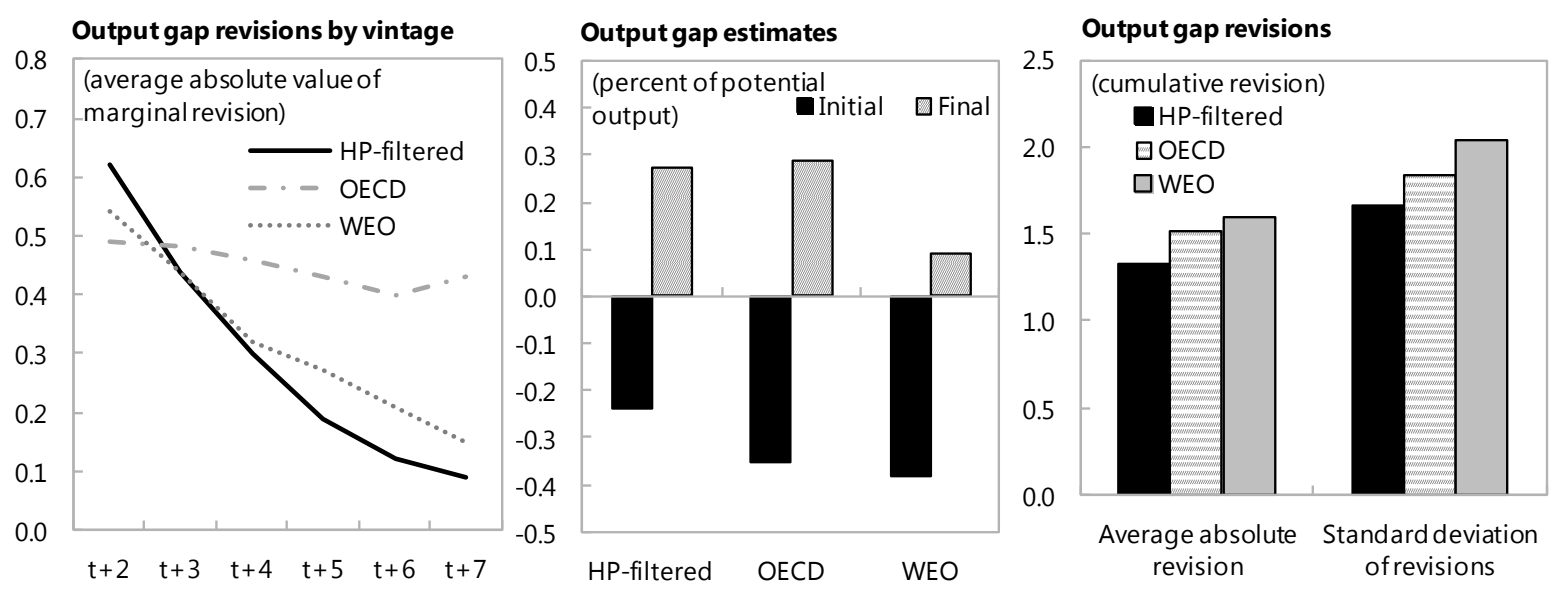

Source: Authors' calculations.

\footnotetext{
${ }^{7}$ See Ravn and Uhlig (2002).
} 
Third, for the United States we analyze output gap estimates based on a production function approach published by the Congressional Budget Office (CBO; see CBO, 2001, for a description of the methodology) in addition to the sources mentioned above. ${ }^{8}$ Figure 5 shows that $\mathrm{CBO}$ and HP-filtered estimates show similar persistent uncertainty, while the distribution of revisions is slightly less wide using CBO estimates. Uncertainty over the sign of the output gap is frequent -7 out of 18 initial estimates change sign by the final estimate for the $\mathrm{CBO}$, OECD, and WEO datasets and 5 out of 18 for the HP-filtered estimates.

Fourth, the results are also robust to adjusting assumptions regarding the filter and sample. ${ }^{9}$ The findings do not change when the full sample is broken into two subsamples covering the 1990s and 2000s. Estimates using filtered data excluding the forecast are even more volatile and subject to revision than those with the forecast included. Finally, the results are insensitive to changing the vintage for the final estimate to six or eight years rather than seven.

Figure 5. Comparison Across U.S. Output Gap Estimates
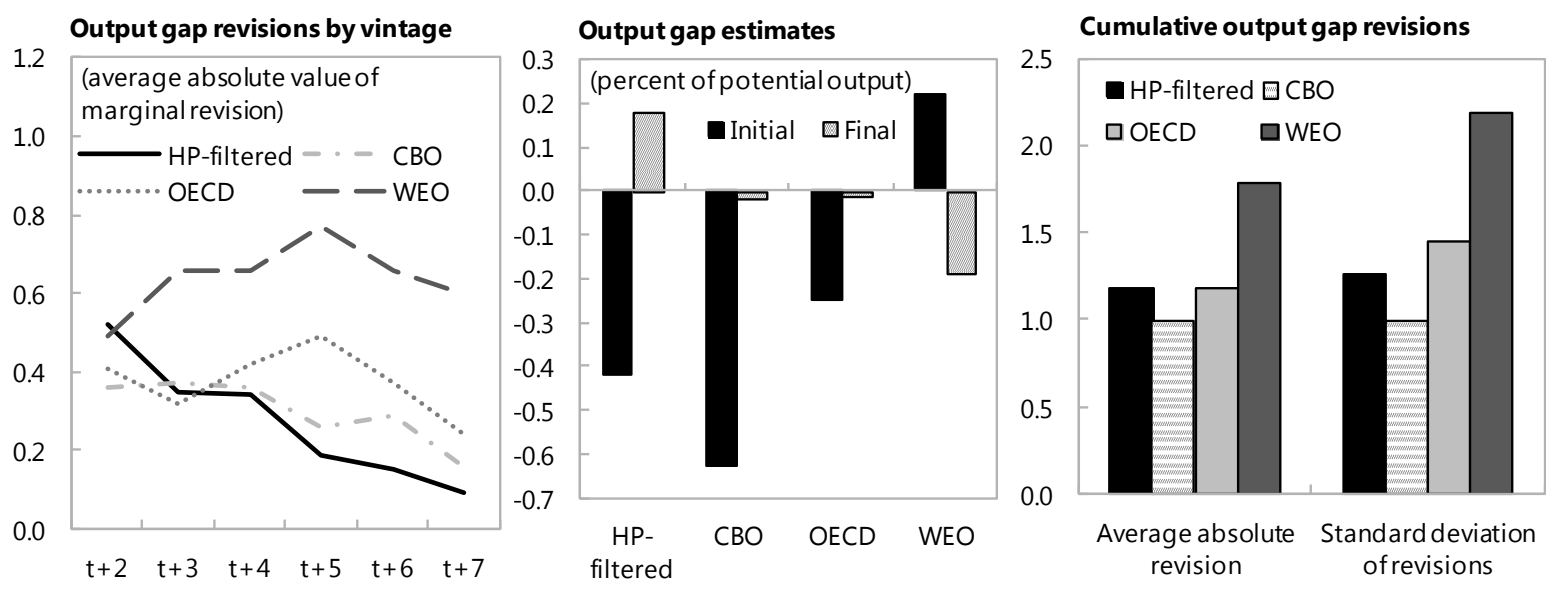

Source: Authors' calculations.

Overall, these results underscore the challenges facing policymakers when setting policy based on assessments of an economy's cyclical position. Assessments made at the time of policy decisions are likely to be revised substantially in subsequent periods, and they likely overstate the degree of excess capacity in the economy. In addition, there is evidence these

\footnotetext{
${ }^{8}$ The estimates are published in January of each year. Vintages are aligned with the WEO and OECD estimates published the preceding September/October and December, respectively, such that the first retrospective estimate of the output gap in year $t$ is assumed to be made in January of year $t+2$; revisions are then made until the final estimate in year $t+8$.

${ }^{9}$ Results for subsamples are not shown since they are very similar to the baseline specification, but they are available from the authors upon request.
} 
problems are more acute during turning points, as revisions tend to be larger during recessions.

\section{DETERMinants OF OUTPUT GaP REVISIONS}

The previous section establishes the wide range of uncertainty that surrounds initial estimates of the output gap. This section looks at whether output gap revisions can be predicted based on either country-specific characteristics or the country's position in the business cycle at the time of the initial estimate. Although we find several significant determinants of output gap revisions, a large share of revisions remains unexplained, suggesting that they may not be predictable at the time policy decisions are made.

\section{A. Empirical Strategy}

Some variables may explain the direction of subsequent output gap revisions, while others may only be informative about the magnitude of revisions. In order to maximize the explanatory power of the information at our disposal at the time of initial estimates, we attempt to explain the size of output gap revisions rather than the direction in which the revisions occur. ${ }^{10}$ Let $\left|\bar{y}_{i, t \mid t+1}-\bar{y}_{i, t \mid t+7}\right|$ denote the absolute value of the cumulative output gap revision for country $i$ at time $t$. This can be modeled as:

$\left|\bar{y}_{i, t \mid t+1}-\bar{y}_{i, t \mid t+7}\right|=\alpha+\beta X_{i, t \mid t+1}+\delta D_{i}+\varepsilon_{i t}$

Where $\alpha$ is the intercept, $X_{i, t \mid t+1}$ is a matrix of variables including the a set of covariates for country $i$ at time $t$ and measured at time $t+1, D_{i}$ is a matrix including other time-invariant covariates measured at the most recent point in time, $\beta$ and $\delta$ are the coefficients on these matrices, and $\varepsilon_{i t}$ is a mean zero error term that captures unexplained heterogeneity.

Equation (2) is estimated using ordinary least squares (OLS) applied to a pooled panel sample of annual observations, correcting the standard errors for heteroskedasticity and autocorrelation. As a robustness check, we also estimate equation (2) with a further correction of the standard errors for cross-sectional dependence.

The selection of the control variables $X_{i, t \mid t+1}$ and $D_{i}$ included in the specifications relies on our understanding, guided by previous empirical research (see, in particular, Ley and Misch, 2014), of what factors may determine the magnitude of the output gap revisions.

\footnotetext{
${ }^{10}$ Note that the revisions of output gap estimates made ex ante would be even less predictable. See Appendix I for a detailed description of the variables.
} 
In order to maximize the usefulness of the findings to policy decisions, we also investigate the determinants of output gap revisions that are large enough to change the sign of the gap, since real-time assessments of whether the economy is above or below potential output play a key role in policy decisions. To investigate the determinants of changes in the sign of the output gap, we estimate the following population-averaged panel probit model ${ }^{11}$ on the same regressors as in the baseline specification:

$\Phi\left(S_{i, t \mid(t+1, t+7)}^{\bar{y}}=1\right)=\alpha+\beta X_{i, t \mid t+1}+\delta D_{i}+\varepsilon_{i t}$

where $\Phi$ is the probability function, and $S_{i, t \mid(t+1, t+7)}^{\bar{Y}}$ is a binary variable taking the value one when the sign of the output gap of country $i$ at time $t$ measured at time $t+7$ is the opposite of the sign of the same output gap measured at time $t+1$. To avoid mild fluctuations around potential GDP, we consider only episodes in which the output gap revision is larger than half a percentage point of potential GDP. Our estimations perform a correction for heteroskedasticity and autocorrelation of the standard errors. ${ }^{12}$

We group the baseline regressors into four categories. A first category includes variables related to domestic or world GDP dynamics. In particular, we control for the size of the output gap measured at $t+1$. A very large positive or negative output gap may signal a change in trend growth that is incorporated only gradually into estimates of potential output and thus we expect a positive impact on the size of revisions. Also, we include domestic and world real GDP growth surprises in time $t$ (measured at time $t+1$ to have actual figures), which are defined as the deviation of domestic (or world) real GDP growth from its mean within the last 10 years. Thus, when a surprise in growth occurs, either domestic or worldwide, it increases the difficulty of decomposing actual output data into its trend and cyclical components, negatively affecting the ability to estimate the output gap and increasing the expected size of its revisions.

A second category of variables attempts to gauge macroeconomic uncertainty. To this end, we use the standard deviation of domestic real GDP growth over the last 10 years measured

\footnotetext{
${ }^{11}$ The alternative is to use logit regressions, assuming an error term that is logistically distributed. As a robustness check, we perform logit regressions that are not shown because they return similar results. Results are available from the authors upon request.

12 The estimated coefficients of a probit model do not quantify the influence of the covariates on the probability of a sign change of the output gap because they are parameters of the latent model. As such, they only measure the effect of a regressor on the latent propensity for a positive result. The effect of a unit change of a covariate on the dependent variable when the other covariates are constant is represented by the marginal effect. This can then be interpreted similarly to the linear regression coefficient, which directly measures the marginal effect of an explanatory variable on the dependent one. Hence, for the probit estimations we only report the corresponding marginal effects.
} 
at $t+1$, as a proxy of historical volatility in the economy. We also include the share of natural resource rents (or economic profits) in GDP to proxy natural resource price movements that are not necessarily reflected in inflation, as well as volume changes. In a broader sense, this variable is a proxy for structural changes in the economy. ${ }^{13}$ It is constructed as the sum of oil, natural gas, coal, mineral, and forest rents, which greatly depend on the corresponding price. Finally, we also include the most commonly used proxy for macroeconomic uncertainty, which is inflation. All these variables are expected to be positively associated with the size of revisions.

A third category of variables captures the presence of policy frameworks. In particular, we include dummy variables for the presence of inflation targeting and fiscal rules that are specified in terms of some fiscal aggregate adjusted for the cycle (here we call them cyclical fiscal rules). These frameworks should activate countercyclical policies which should help keep output relatively near its trend level, reducing the size of revisions. Fiscal rules, however, are often introduced when fiscal discipline is weak and their adoption can be accompanied by significant adjustments when conditions for triggering escape clauses are not met. Thus, the expected effect on output gap revisions is ambiguous.

A last category of variables is supposed to capture the degree of statistical capacity common to different groups of countries. Advanced economies are likely to have good and timely data and thus revisions to actual data and the output gap are expected to be smaller. In contrast, data timeliness and availability is more heterogeneous in low-income countries (LICs), possibly affecting the reliability of initial releases of GDP data and increasing the size of output gap revisions. This is similar to what happens in a number of small economies (those with a population below the $10^{\text {th }}$ percentile of the population distribution). Beyond data quality, LICs and small economies may be subject to shocks (such as natural disasters) whose effects are hard to decompose between the trend and the cycle in real time. These three factors are represented by dummy variables.

\section{B. Results}

Table 4 presents evidence on the determinants of the cumulative absolute revisions of the output gap. We run the baseline specification on an unbalanced sample of 2,943 observations for 171 countries over the period 1990-2007 using the baseline dataset of HP-filtered real GDP data. For robustness, we estimate the same specification using estimates for the output gap provided to the WEO by country desks, as well as OECD estimates, and by running an alternate specification that corrects the standard errors for cross-sectional dependence. As the WEO output gap estimates cover only 29 countries (26 countries in the case of the OECD),

\footnotetext{
${ }^{13}$ Since there are no vintages available for rents in percent of GDP, we assume that the data are the same as at time $t+1$.
} 
Table 4. Determinants of the Absolute Revisions of the Output Gap, Baseline (Dependent variable: absolute revisions of the output gap at $t+7$ compared to $t+1$ )

\begin{tabular}{|c|c|c|c|c|c|c|}
\hline & \multirow{2}{*}{\multicolumn{2}{|c|}{$\begin{array}{cc}(1) & (2) \\
\text { HP filtered WEO data }\end{array}$}} & \multirow{2}{*}{\multicolumn{2}{|c|}{$\begin{array}{l}(3) \\
\text { WEO data }\end{array}$}} & \multirow{2}{*}{\multicolumn{2}{|c|}{$\begin{array}{l}(5) \quad(6) \\
\text { OECD data }\end{array}$}} \\
\hline & & & & & & \\
\hline & OLS & OLS PCSE & OLS & OLS PCSE & OLS & OLS PCSE \\
\hline \multirow[t]{2}{*}{ Abs. output gap \# } & $0.109^{\star \star *}$ & $0.104^{\star \star \star}$ & $0.658^{\star \star \star}$ & $0.613^{\star \star \star}$ & $0.180^{\star * \star}$ & 0.134 \\
\hline & $(0.035)$ & $\begin{array}{l}(0.022) \\
0.049^{\star * *}\end{array}$ & $(0.161)$ & $(0.070)$ & $(0.040)$ & $\begin{array}{c}(0.083) \\
0.034\end{array}$ \\
\hline Abs. real GDP growth surprise \# & $\begin{array}{l}0.0 / 4 \\
(0.014)\end{array}$ & $(0.018)$ & $\begin{array}{l}-0.035 \\
(0.069)\end{array}$ & $\begin{array}{l}-0.026 \\
(0.057)\end{array}$ & $\begin{array}{l}0.043 \\
(0.083)\end{array}$ & $(0.089)$ \\
\hline \multirow[t]{2}{*}{ Abs. world real GDP growth surprise \# } & $0.189^{* \star}$ & 0.085 & $0.801^{\star \star \star}$ & $0.568^{\star \star \star}$ & $0.925^{\star \star \star}$ & $0.612^{\star \star \star}$ \\
\hline & $(0.077)$ & $(0.065)$ & $(0.142)$ & $(0.125)$ & $(0.188)$ & $(0.138)$ \\
\hline \multirow[t]{2}{*}{ Real GDP growth SD \# } & 0.005 & 0.008 & -0.014 & -0.047 & -0.019 & -0.005 \\
\hline & $(0.020)$ & $(0.028)$ & $(0.071)$ & $(0.085)$ & $(0.139)$ & $(0.152)$ \\
\hline \multirow[t]{2}{*}{ Rents/GDP } & $0.020^{\star \star \star}$ & $0.021^{\star \star \star}$ & -0.002 & -0.007 & $-0.054^{\star \star *}$ & $-0.056^{* *}$ \\
\hline & $(0.007)$ & $(0.006)$ & $(0.016)$ & $(0.036)$ & $(0.013)$ & $(0.023)$ \\
\hline \multirow[t]{2}{*}{ Inflation } & 0.009 & $0.009^{\star}$ & -0.061 & -0.039 & $0.114^{* *}$ & 0.119 \\
\hline & $(0.007)$ & $(0.005)$ & $(0.060)$ & $(0.044)$ & $(0.055)$ & $(0.075)$ \\
\hline \multirow[t]{2}{*}{ Inflation targeting } & $-0.362^{\star \star \star}$ & $-0.330^{\star *}$ & -0.107 & -0.171 & -0.235 & -0.225 \\
\hline & $(0.135)$ & $(0.154)$ & $(0.191)$ & $(0.217)$ & $(0.191)$ & $(0.218)$ \\
\hline \multirow[t]{2}{*}{ Cyclical fiscal rules } & 0.056 & 0.091 & 0.058 & 0.067 & 0.130 & 0.138 \\
\hline & $(0.167)$ & $(0.178)$ & $(0.201)$ & $(0.232)$ & $(0.218)$ & $(0.188)$ \\
\hline \multirow[t]{2}{*}{ OECD } & $-0.542^{* * *}$ & $-0.594^{\star \star \star}$ & & & & \\
\hline & $(0.151)$ & $(0.140)$ & & & & \\
\hline \multirow[t]{2}{*}{ LIC } & $0.503^{\star \star}$ & $0.522^{\star *}$ & & & & \\
\hline & $(0.230)$ & $(0.212)$ & & & & \\
\hline \multirow[t]{2}{*}{ Small economy } & $0.790^{\star \star \star}$ & $0.745^{\star \star \star}$ & & & & \\
\hline & $(0.216)$ & $(0.242)$ & & & & \\
\hline \multirow[t]{2}{*}{ Constant } & $1.437^{\star \star \star}$ & $1.685^{\star \star \star}$ & 0.189 & $0.544^{\star \star}$ & 0.328 & $0.685^{*}$ \\
\hline & $(0.157)$ & $(0.165)$ & (0.333) & $(0.255)$ & $(0.296)$ & $(0.366)$ \\
\hline Observations & 2,943 & 2,943 & 437 & 437 & 299 & 299 \\
\hline R-squared & 0.164 & 0.109 & 0.407 & 0.382 & 0.157 & 0.100 \\
\hline Number of economies & 171 & 171 & 29 & 29 & 26 & 26 \\
\hline
\end{tabular}

the number of observations falls to about a sixth when using WEO estimates (and to a tenth when using OECD estimates). When using WEO and OECD estimates, the dummy variables for OECD countries, LICs, and small economies are no longer applicable.

Column 1 presents the results for our preferred estimation. Most of the variables' coefficients are significant and take the expected sign. A one percentage point increase in the (absolute value of the) output gap is associated with a 0.11 percentage point increase in its revision. Similarly, real GDP growth surprises positively affect revisions. A one percentage point increase in the deviation of domestic real GDP growth from its past 10 years' mean raises the revision by 0.07 percentage points, while a one percentage point increase in the deviation of 
the world real GDP growth from its past 10 years' mean raises the revision by 0.19 percentage points.

Evidence on the effects of macroeconomic uncertainty on output gap revisions is mixed. The coefficient on historical growth volatility is insignificant, suggesting that historically volatile countries are not subject to greater uncertainty around output gap estimates. However, estimating output gaps for resource rich countries is more challenging, as an increase of one percentage point in rents as a share of GDP brings about an increase in the revision by 0.02 percentage points.

Countries with inflation targeting regimes have lower output gap revisions. Indeed, these countries have output gap revisions that are 0.36 percentage points lower than other countries, holding other factors constant. In contrast, fiscal rules are not reflected in any significant change in the size of the revisions.

Quality (including timeliness) of data is a statistically significant determinant of the revisions. OECD countries have revisions over half a point smaller than those of other countries, while LICs have revisions that are about half a point larger than other countries. Small countries have even larger revisions -0.79 percentage points greater than the rest of the sample.

Some robustness checks are performed on the preferred specification. The results after correcting for cross-sectional dependence of standard errors are very similar, suggesting that such dependence is not pervasive in the data (Column 2). Also, the results when using WEO output gap estimates (Columns 3 and 4) and OECD estimates (Columns 5 and 6) are generally consistent, though the size of the statistically significant coefficients is larger in some cases. For example, the magnitude of the coefficients for the size of the output gap and surprises in world real GDP growth are about six and four times larger, respectively, when WEO data are used, and 11/4 and 4 times larger when OECD data are used. On the other hand, the coefficients for real GDP growth volatility and inflation targeting regime are significant when OECD data are used and maintain a similar magnitude.

Two variables become statistically significant when using OECD output gap estimates. Rents (as a share of GDP) take a negative sign suggesting that the size of the revisions is smaller when the country is resource rich. This (rather counterintuitive) result is mainly driven by the large rents in Norway, Canada, and Australia, countries with a high degree of macroeconomic stability. The estimation of a regression including an interaction term between rents and a dummy variable taking a value of one for these three countries yields a non-significant coefficient on rents. All these robustness checks should be taken with caution as the sample is only a fraction of the one in Column 1. Also, the subset of countries used in 
Columns 3 to 6 may suffer from selection bias because the countries included are mainly advanced economies. ${ }^{14}$

Finally, we run the same specifications in Columns 1 and 2 using HP-filtered WEO data that are generated by $\lambda$ equal to 6.25 . The results are very similar to the ones reported in Columns 1 and 2 and suggest that the choice of the smoothing parameter does not affect the main conclusions. ${ }^{15}$

The goodness of fit of the different specifications falls in the 10 to 41 percent range. This suggests that a large component of the revisions behaves as a white noise process, and thus, it cannot be explained by factors known to policymakers.

We also estimate the baseline specification without dummy variables for country groups. One may argue these dummies pick up effects other than the ones they are constructed for and that, as a result, the explanatory power may be even lower than in the baseline estimation. The results, however, suggest that this is not the case as the continuous variables present similar coefficients and the R-squared is close to the one of the baseline, so the results are not shown.

In order to reduce the likelihood of omitted variable bias, in Table 5 we present some extensions to the baseline specification. The baseline results are generally robust when other explanatory variables are added. First, we test if adherence to data dissemination standards defined by the IMF, the General Data Dissemination System (GDDS) or the Special Data Dissemination Standard (SDDS) ${ }^{16}$, affect the size of the revisions. While we expect a negative effect, the results are insignificant (Column 1).

Social or political conflicts can be detrimental to output gap estimation because of the destruction of human and physical capital (including assessing the impact on the economy's productive capacity). To capture this, we include a dummy variable taking a value of one if the loss of life due to conflict is considerable, and expect it to be positively associated with the size of the revisions. We find the coefficient on this dummy to be statistically insignificant (Column 2).

\footnotetext{
${ }^{14} \mathrm{We}$ also run a specification including a dummy taking value one during the 1990s to explore whether there was a change over time in the size of the revisions. However, the coefficient is not statistically significant.

${ }^{15}$ Results are available from the authors upon request.

${ }^{16}$ The difference between the two standards is the level of data requirements, with the SDDS being more demanding.
} 


\section{Table 5. Determinants of the Absolute Revisions of the Output Gap, Extensions}

(Dependent variable: absolute revisions of the output gap at $t+7$ compared to $t+1$; HP filtered data)

Abs. output gap \#

Abs. real GDP growth surprise \#

Abs. world real GDP growth surprise \#

Real GDP growth SD \#

Rents/GDP

Inflation

Inflation targeting

Cyclical fiscal rules

OECD

LIC

Small economy

GDDS

SDDS

Bureaucratic quality

Control of corruption

Abs. average future real GDP growth differential

Constant

Observations

R-squared

Number of economies
Conflict

(2)

(3)

$$
\begin{gathered}
0.109^{\star * *} \\
(0.035) \\
0.074^{\star * *} \\
(0.014) \\
0.200^{\star *} \\
(0.077) \\
0.003 \\
(0.020) \\
0.021^{\star \star \star} \\
(0.007) \\
0.009 \\
(0.007) \\
-0.394^{\star * *} \\
(0.150) \\
0.048 \\
(0.172) \\
-0.578^{* \star *} \\
(0.156) \\
0.542^{\star *} \\
(0.238) \\
0.828^{\star * *} \\
(0.219) \\
-0.254 \\
(0.214) \\
0.036 \\
(0.155)
\end{gathered}
$$$$
0.074^{\star * *} \quad 0.074^{\star * *}
$$$$
(0.014) \quad(0.014)
$$$$
0.200^{* *} \quad 0.189^{* *}
$$$$
(0.077)
$$$$
0.005
$$$$
(0.020)
$$$$
0.020^{\star \star *}
$$$$
(0.007)
$$$$
0.010
$$$$
(0.007)
$$$$
-0.361^{* * *}
$$$$
(0.134)
$$$$
0.053
$$$$
(0.167)
$$$$
-0.544^{* * *}
$$$$
(0.150)
$$$$
0.506^{\star \star}
$$$$
\text { (0.230) }
$$

$-0.166$

(0.291)

$$
\begin{aligned}
& -0.086 \\
& (0.081)
\end{aligned}
$$

$-0.074$

(0.059)

$0.123^{\star \star *}$

(0.036)

\begin{tabular}{ccccc}
$1.458^{\star * *}$ & $1.441^{* * *}$ & $1.484^{\star * *}$ & $1.494^{\star \star *}$ & $1.327^{\star \star *}$ \\
$(0.170)$ & $(0.156)$ & $(0.251)$ & $(0.218)$ & $(0.156)$ \\
& & & & \\
2,943 & 2,943 & 2,241 & 2,241 & 2,942 \\
0.165 & 0.164 & 0.183 & 0.183 & 0.185 \\
171 & 171 & 129 & 129 & 171 \\
\hline
\end{tabular}

Notes: All estimations are performed with pooled OLS; heteroskedasticity and autocorrelation robust standard errors in parentheses; ${ }^{* * *},{ }^{* *},{ }^{*}$ next to a number indicate statistical significance at 1,5 and 10 percent, respectively; \# denotes variables measured at time $t+1$.

Source: Authors' calculations. 
Also, we control for institutional quality. Corruption or low bureaucratic quality may negatively affect data quality and data production processes. For example, if institutional quality is weak, there may be scope for data manipulation with the aim of obtaining political advantage. Hence, we expect the coefficients on both variables to be negative. The estimation yields statistically insignificant coefficients (Columns 3 and 4).

Finally, we introduce information about future GDP growth. In principle, a sharp acceleration or slowdown in growth after year $t$ should play a role in revisions to the estimated output gap in $t$ by changing the decomposition of actual data into trend and cycle. We measure the change in future growth by taking the absolute value of the difference in average GDP growth between the five years following $t$ and the five years preceding it. The coefficient on this variable is significant and indicates that an absolute change of one percentage point in future growth increases the size of the output gap revision by 0.12 percentage points. The incorporation of this variable turns the coefficient on the (absolute) size of the output gap insignificant, suggesting some redundancy between the two. Moreover, the increase in explanatory power is modest (Column 5). ${ }^{17}$

Similar to the robustness check for the baseline specification, we exclude the dummy variables for country groups and re-estimate Columns 1 to 5. While the coefficients for the continuous variables show similar magnitudes, bureaucratic quality, and control of corruption turn significant with the expected negative sign, suggesting a fairly high degree of correlation with the excluded dummies (results not shown).

Table 6 shows the marginal effects derived from the probit estimations on the baseline dataset of HP-filtered WEO data. Column 1 presents the results using the same baseline specification as in Table 4. A one percentage point increase in the size of the output gap reduces the probability of a change in the sign of the output gap by 0.07 percent. This result (along with the findings of a positive association between an increase in the size of the output gap and the size of the revisions) suggests that countries that are far away from the potential output are unlikely to have revisions large enough to change the sign of the output gap. Also, real GDP growth surprises increase the probability of the output gap changing sign, but to a smaller extent.

Macroeconomic uncertainty affects the probability of a sign change in the output gap during the revision period, but the size of the coefficient is relatively small. An increase in inflation by one percentage point increases such probability by 0.002 percent. Being an inflation targeter reduces the probability of a sign change by 0.09 percent. Interestingly, countries with

\footnotetext{
${ }^{17}$ As in Ley and Misch (2013), we test if countries with an IMF program have higher output gap revisions (see Dreher et al., 2008), and the coefficient is insignificant.
} 
cyclical fiscal rules are more likely to observe changes in the sign of the output gap during the revision period by 0.12 percent.

Table 6. Determinants of the Probability of the Output Gap Changing Sign (Dependent variable: binary variable, 1 if output gap changes sign at $t+7$; HP filtered data; marginal effects)

\begin{tabular}{|c|c|c|c|c|c|c|}
\hline & $(1)$ & $(2)$ & (3) & $(4)$ & $(5)$ & (6) \\
\hline Abs. output gap \# & $\begin{array}{c}-0.071^{* * *} \\
(0.007)\end{array}$ & $\begin{array}{c}-0.071^{* * *} \\
(0.007)\end{array}$ & $\begin{array}{c}-0.071^{* * *} \\
(0.007)\end{array}$ & $\begin{array}{c}-0.087^{* * *} \\
(0.007)\end{array}$ & $\begin{array}{c}-0.086^{* * *} \\
(0.007)\end{array}$ & $\begin{array}{c}-0.065^{\star * *} \\
(0.007)\end{array}$ \\
\hline Abs. real GDP growth surprise \# & $\begin{array}{l}0.005^{*} \\
(0.003)\end{array}$ & $\begin{array}{l}0.005^{\star} \\
(0.003)\end{array}$ & $\begin{array}{l}0.005^{\star} \\
(0.002)\end{array}$ & $\begin{array}{c}0.003 \\
(0.002)\end{array}$ & $\begin{array}{c}0.003 \\
(0.002)\end{array}$ & $\begin{array}{c}0.008^{\star * *} \\
(0.002)\end{array}$ \\
\hline Abs. world real GDP growth surprise \# & $\begin{array}{c}0.009 \\
(0.014)\end{array}$ & $\begin{array}{c}0.012 \\
(0.014)\end{array}$ & $\begin{array}{c}0.009 \\
(0.014)\end{array}$ & $\begin{array}{c}0.001 \\
(0.016)\end{array}$ & $\begin{array}{c}0.003 \\
(0.016)\end{array}$ & $\begin{array}{c}0.006 \\
(0.014)\end{array}$ \\
\hline Real GDP growth SD \# & $\begin{array}{c}0.000 \\
(0.004)\end{array}$ & $\begin{array}{l}-0.000 \\
(0.004)\end{array}$ & $\begin{array}{c}0.000 \\
(0.004)\end{array}$ & $\begin{array}{c}0.006 \\
(0.003)\end{array}$ & $\begin{array}{c}0.006^{*} \\
(0.003)\end{array}$ & $\begin{array}{c}0.002 \\
(0.004)\end{array}$ \\
\hline Rents/GDP & $\begin{array}{l}-0.000 \\
(0.001)\end{array}$ & $\begin{array}{l}-0.000 \\
(0.001)\end{array}$ & $\begin{array}{l}-0.000 \\
(0.001)\end{array}$ & $\begin{array}{l}-0.001 \\
(0.001)\end{array}$ & $\begin{array}{l}-0.001 \\
(0.001)\end{array}$ & $\begin{array}{c}0.000 \\
(0.001)\end{array}$ \\
\hline Inflation & $\begin{array}{l}0.002^{\star *} \\
(0.001)\end{array}$ & $\begin{array}{l}0.002^{*} \\
(0.001)\end{array}$ & $\begin{array}{l}0.002^{\star *} \\
(0.001)\end{array}$ & $\begin{array}{l}0.002^{\star *} \\
(0.001)\end{array}$ & $\begin{array}{l}0.002^{\star *} \\
(0.001)\end{array}$ & $\begin{array}{l}0.002^{\star *} \\
(0.001)\end{array}$ \\
\hline Inflation targeting & $\begin{array}{c}-0.085^{* * *} \\
(0.026)\end{array}$ & $\begin{array}{c}-0.055^{\star *} \\
(0.028)\end{array}$ & $\begin{array}{c}-0.085^{\star * *} \\
(0.026)\end{array}$ & $\begin{array}{c}-0.077^{\star * *} \\
(0.025)\end{array}$ & $\begin{array}{c}-0.081^{\star * *} \\
(0.025)\end{array}$ & $\begin{array}{c}-0.085^{\star \star *} \\
(0.025)\end{array}$ \\
\hline Cyclical fiscal rules & $\begin{array}{c}0.116^{*} \\
(0.068)\end{array}$ & $\begin{array}{l}0.143^{\star *} \\
(0.068)\end{array}$ & $\begin{array}{c}0.116^{*} \\
(0.068)\end{array}$ & $\begin{array}{l}0.112^{*} \\
(0.068)\end{array}$ & $\begin{array}{c}0.102 \\
(0.068)\end{array}$ & $\begin{array}{l}0.114^{*} \\
(0.067)\end{array}$ \\
\hline OECD & $\begin{array}{c}-0.135^{\star * *} \\
(0.029)\end{array}$ & $\begin{array}{c}-0.131^{\star * *} \\
(0.029)\end{array}$ & $\begin{array}{c}-0.135^{\star \star \star} \\
(0.029)\end{array}$ & $\begin{array}{c}-0.102^{* * *} \\
(0.035)\end{array}$ & $\begin{array}{c}-0.141^{* * *} \\
(0.031)\end{array}$ & $\begin{array}{c}-0.133^{\star * *} \\
(0.029)\end{array}$ \\
\hline LIC & $\begin{array}{c}0.106^{\star * *} \\
(0.037)\end{array}$ & $\begin{array}{c}0.100^{\star * *} \\
(0.037)\end{array}$ & $\begin{array}{c}0.106^{\star \star \star} \\
(0.036)\end{array}$ & $\begin{array}{l}0.100^{\star *} \\
(0.051)\end{array}$ & $\begin{array}{c}0.130^{* * *} \\
(0.049)\end{array}$ & $\begin{array}{c}0.096^{\star * *} \\
(0.037)\end{array}$ \\
\hline Small economy & $\begin{array}{c}0.050 \\
(0.041)\end{array}$ & $\begin{array}{c}0.039 \\
(0.042)\end{array}$ & $\begin{array}{c}0.050 \\
(0.041)\end{array}$ & & & $\begin{array}{c}0.065 \\
(0.042)\end{array}$ \\
\hline GDDS & & $\begin{array}{l}-0.039 \\
(0.029)\end{array}$ & & & & \\
\hline SDDS & & $\begin{array}{c}-0.071^{\star * *} \\
(0.026)\end{array}$ & & & & \\
\hline Conflict & & & $\begin{array}{l}-0.021 \\
(0.053)\end{array}$ & & & \\
\hline Bureaucratic quality & & & & $\begin{array}{l}-0.022 \\
(0.015)\end{array}$ & & \\
\hline Control of corruption & & & & & $\begin{array}{c}0.010 \\
(0.011)\end{array}$ & \\
\hline Abs. average future real GDP growth differential & & & & & & $\begin{array}{c}-0.019^{* * *} \\
(0.005)\end{array}$ \\
\hline Observations & 2,943 & 2,943 & 2,943 & 2,241 & 2,241 & 2,942 \\
\hline Number of economies & 171 & 171 & 171 & 129 & 129 & 171 \\
\hline
\end{tabular}

Statistical capacity matters. Consistent with the results of Tables 4 and 5, being an OECD country reduces the probability of a sign change in the output gap by 0.14 percent, while being a LIC increases it by 0.11 percent. 
Columns 2 to 6 report the results of extensions to the baseline specification. The baseline regressors are robust, with the exception of real GDP growth surprises which loses significance when the institutional quality variables are included and the dummy for small economies is dropped. Among the additional regressors, SDDS (but not GDDS) is significant and takes the expected negative sign. A shift in future GDP growth relative to past GDP growth reduces the probability of the output gap switching sign. These results are robust to the exclusion of country group dummies from the specification.

Overall, these regressions predict a low share of the variation in output gap revisions. Given that they make use of some information that is not known until after the period under analysis, it is reasonable to expect that the predictability of output gap revisions ex ante, when it would be useful for policy decisions, is even lower.

\section{Policy Implications}

This paper has illustrated the wide range of uncertainty that typically characterizes assessments of the cyclical position of economies around the world. It has also shown that only a small share of this uncertainty is likely to be explained by factors known to policymakers in real time. This section illustrates some policy implications of these findings, focusing on five Latin American economies (LA-5) that have implemented active countercyclical monetary policies over the last decade.

\section{A. To Ease, or to Tighten?}

The historical output gap data and revisions described above can be used to construct a confidence interval around any initial or revised estimate of the output gap. The width of the confidence interval will vary by country, depending on the historical distribution of its output gap revisions. It will also vary by the vintage of revision, with a wider confidence interval for an initial estimate than for a revised estimate that is closer in time to the final estimate.

Figure 6 shows initial estimates of the output gap for Brazil, Chile, Colombia, Mexico, and Peru for 2008-13. Figure 6 also shows confidence intervals calculated using the distribution of cumulative revisions to initial estimates over 1990-2007. The magnitude of the confidence intervals encompasses a wide range of potential outcomes. Only in rare cases is there a high degree of certainty about whether policy should be contractionary, neutral, or expansionary; for most countries in most years, there is a non-negligible probability that the appropriate policy could be in any of those three categories. 
Figure 6. Real-Time Output Gap Estimates and Confidence Intervals

(Output gap in percent of potential GDP)
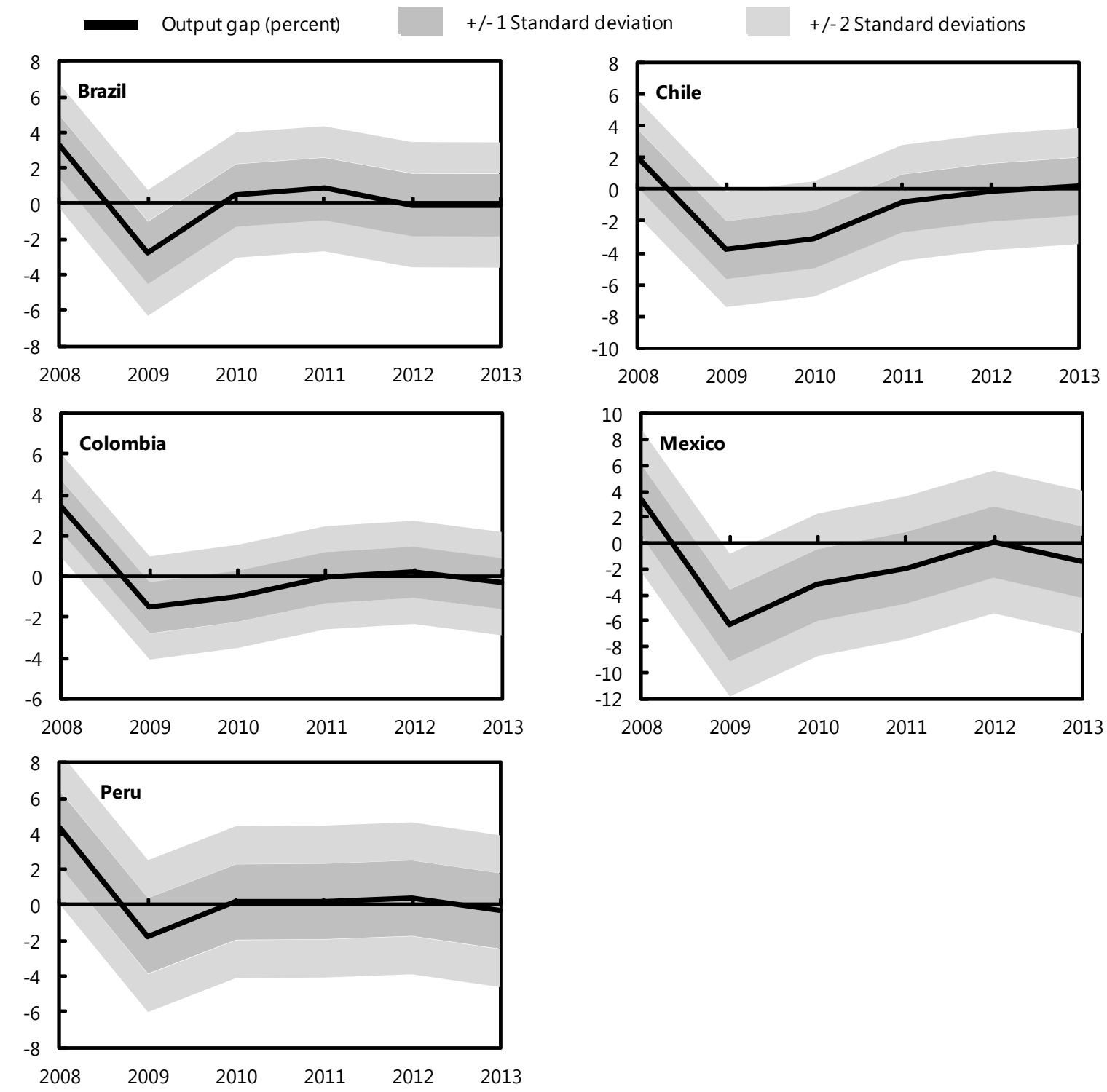

Sources: IMF, World Economic Outlook database; and authors' calculations.

\section{B. Setting Monetary Policy in Real Time}

The confidence intervals provide a broad view of how uncertain the cyclical position of any economy is, but are based on annual observations, so are less applicable for monetary policy decisions that make use of higher-frequency data. In this section, we construct real-time quarterly output gap estimates and use them to estimate monetary policy reaction functions based on real-time data. 
The LA-5 mentioned above all adopted inflation targeting as their monetary policy framework between 1999 and 2002 (Roger, 2010). Assessing the economy's actual level of output relative to its potential is a key element of inflation targeting. This is because the degree of spare capacity is typically an important predictor of future inflation, the ultimate objective for policy decisions under inflation targeting.

The output gap is not the only indicator of the degree of spare capacity, but it is one of the broadest and is frequently used both in models of monetary policy and in policy decisions. Alternative indicators such as the unemployment rate can also be useful but have other shortcomings, including being dependent on labor participation rates, which can change over time. Combinations of variables may outperform any individual variable, but for each indicator of spare capacity the fundamental challenge is the same as for the output gapdecomposing observed data into its cyclical and trend components. Thus, while central banks analyze a wide variety of indicators in assessing the cyclical position of an economy, this section uses the output gap to summarize economy-wide spare capacity and illustrates the implications of output gap revisions for the appropriate settings of monetary policy. ${ }^{18}$

An inflation-targeting central bank sets policy so as to minimize the deviation of actual inflation $\pi_{t}$ from the target $\pi^{*}$, as in the following loss $(\gamma)$ function:

$\gamma=\operatorname{Var}\left(\pi_{t}-\pi^{*}\right)$

Since monetary policy affects economic activity with a lag and activity affects prices with a lag, the policy instrument $r_{t}$-which in the countries analyzed here is the rate at which the central bank makes short-term loans to commercial banks - is set with respect to the expected value at time $t$ of the deviation of future inflation (at time $t+i$ ) from the target $\left(\pi_{t+i \mid t}-\pi^{*}\right)$ given the current information set:

$r_{t}=f\left\{E\left(\pi_{t+i \mid t}-\pi^{*}\right)\right\}$

Conceptually, any information that could help predict future inflation would have a place in the central bank's reaction function. This could potentially include a wide array of variables or non-quantitative information (for example, on prospective harvests of key agricultural products). In practice, the inflation expectations of market participants should account for all publicly-available information relevant to inflation at a given point in time, and could thus serve as a proxy. Given this paper's interest in the impact of domestic capacity utilization on

\footnotetext{
${ }^{18}$ The output gap is also an indicator for which forecasts tend to be more readily available. This permits estimation of the cyclical and trend components over both historical and forecast data points, thus mitigating the endpoint problem found in most filtering methods.
} 
inflation, the output gap $\left(\bar{y}_{t}\right)$ is included separately. ${ }^{19}$ Thus, the central bank's reaction function can be modeled as:

$r_{t}=f\left\{\left(\pi_{t+i \mid t}^{m}-\pi^{*}\right), \bar{y}_{t}\right\}$

where $\pi_{t+i \mid t}^{m}$ represents the inflation expectations of market participants at the horizon relevant for monetary policy. Expectational channels are typically strong in inflationtargeting regimes because of the forward-looking nature of policy, which advocates the use of the lagged policy rate in empirical estimation (Woodford, 1999; Orphanides, 2001). The estimated reaction function is then:

$r_{t}=\rho r_{t-1}+(1-\rho)\left(\alpha_{0}+\alpha_{\pi} \pi_{t+i \mid t}+\alpha_{\bar{y}} \bar{y}_{t-1}\right)+\eta_{t}$

The persistence parameter on the lagged monetary policy rate is $\rho, \alpha_{\pi}$ and $\alpha_{\bar{y}}$ are the responses of monetary policy to expected inflation and the output gap, respectively, and $\eta_{t}$ is the error term. The expected future output gap is not included because the transmission lag from the output gap to inflation implies that the current or lagged output gap is more relevant for future inflation; here the first lag is used since the initial estimate based on actual data is available by the end of the following quarter. However, given the method for estimating the output gap described below, even the lagged output gap embodies information on the expectations of market participants concerning output growth in subsequent quarters (the results are insensitive to using the forecast of the contemporaneous output gap).

The output gap is computed using an HP filter with a smoothing parameter of 1600 . In order to mitigate the endpoint problem implicit in filtering, actual data on real GDP was merged with the real GDP growth expectations data to form a series extending between five and eight quarters beyond the endpoint of actual data at any given point in time. This extended series is then filtered, and the output gap calculated for the last available data point.

Figure 7 compares the real-time series with the one resulting from data available up to the second quarter of 2014. Note that differences in recent periods tend to be smaller, since actual data has not gone through as many revisions, and there have been fewer subsequent periods providing new information on the decomposition of actual data into its structural and trend components.

Nevertheless, there are some substantial differences. For Brazil, the latest estimate suggests that the economy was operating at a higher rate of capacity utilization from 2010 to 2012 than given by initial estimates. Initial estimates of output relative to potential were also revised up substantially in Chile and Mexico from 2006 to 2008 and Colombia in 2008.

\footnotetext{
${ }^{19}$ This will directly capture the central bank's response to the output gap, implicitly incorporating the central bank's expectation of the impact of the output gap on inflation.
} 
Initial estimates for Peru signaled that output was above potential from 2005 to 2007, a finding that was later reversed as potential output was subsequently revised upward.

Figure 7. Quarterly Output Gap Estimates for LA-5 Economies (Output gap in percent of potential GDP)
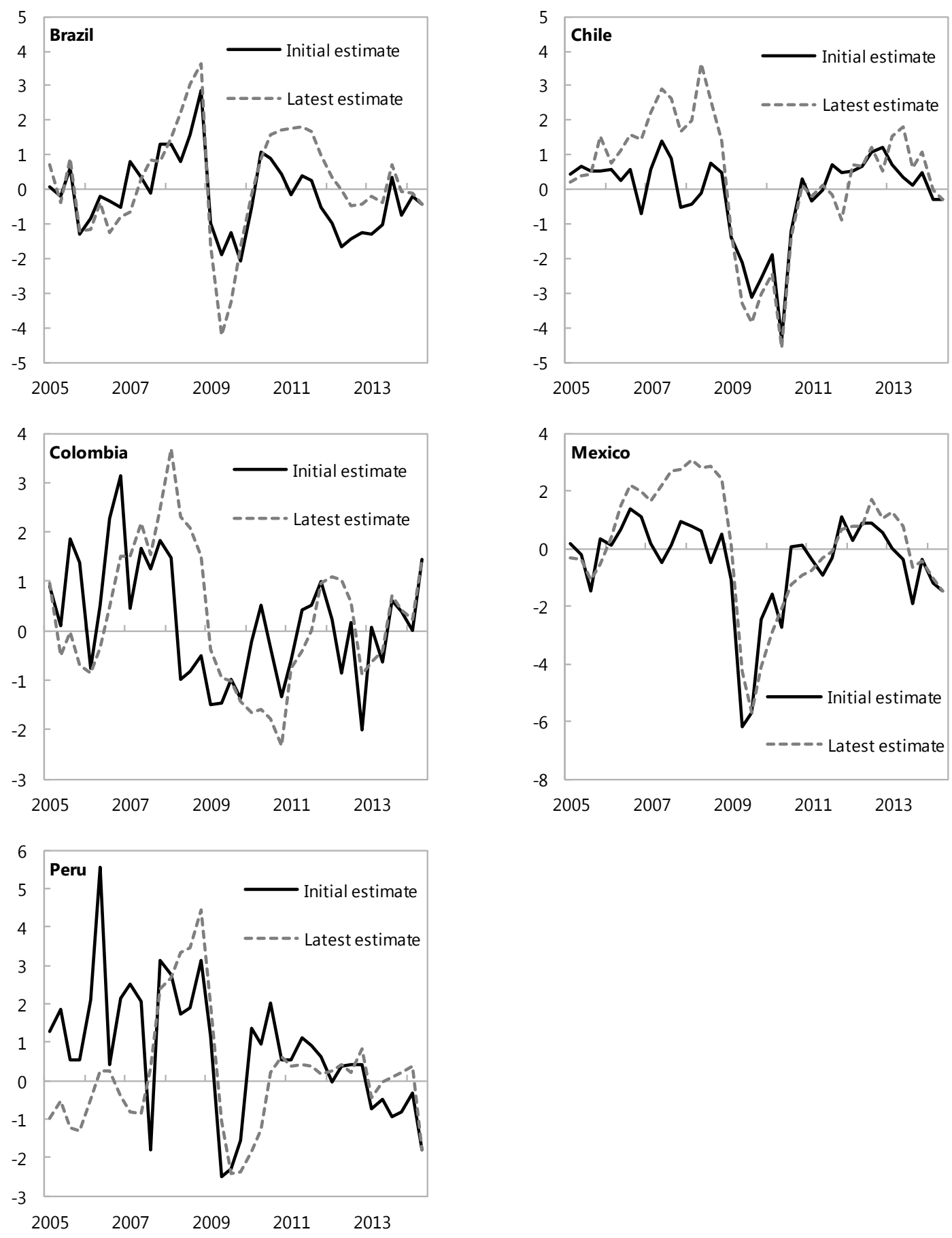

Sources: National authorities; and authors' calculations. 


\section{Monetary Reaction Functions}

We estimate the policy reaction function (7) for each country using the real-time output gap estimated above and the inflation expectations of market participants surveyed by the respective central banks. The monetary policy rate is measured as the end-quarter rate; thus, it should take into account all information available as of the last month of the quarter, including real GDP data for the previous quarter, plus expected inflation and real GDP growth in the central bank survey from that month. Estimation begins in 2005, coinciding with the availability of real-time GDP data for the LA-5 countries.

Table 7 shows the estimated monetary policy reaction functions. Since the data used is available in real time, the estimation is performed using OLS (see Orphanides, 2001). ${ }^{20}$ In all cases, the central bank reacts strongly to increases in inflation expectations, and the response is statistically significant except for Brazil. A response greater than one implies that central banks increase real interest rates when an increase in inflation is expected, which is a necessary condition for maintaining price stability. LA-5 central banks also countered increases in the output gap by raising interest rates $\left(\alpha_{\bar{y}}\right.$ is positive and statistically significant in all cases). Given these characteristics of policy, expectations were generally wellanchored, and the coefficient on the lagged interest rate is strongly significant in all cases. Overall, the functions provide a close fit to actual policy interest rates over 2005-2014.

Table 7. Monetary Policy Reaction Functions

(Dependent variable: monetary policy rate)

\begin{tabular}{lrcccc}
\hline & Brazil & Chile & Colombia & Mexico & \multicolumn{1}{c}{ Peru } \\
\hline$\alpha_{0}$ & 4.72 & $4.59 * *$ & $2.52 * *$ & $1.94 * *$ & $2.91 * *$ \\
& $(3.78)$ & $(0.24)$ & $(0.58)$ & $(0.88)$ & $(0.98)$ \\
$\alpha_{\pi}$ & 1.16 & $3.04 * *$ & $3.18 *$ & $2.51 * *$ & $1.56 * *$ \\
& $(0.7)$ & $(0.38)$ & $(1.63)$ & $(0.96)$ & $(0.49)$ \\
$\alpha_{\mathrm{y}}$ & $1.89 * *$ & $0.96 * *$ & $0.74 * *$ & $0.43 * *$ & $0.88 *$ \\
& $(0.71)$ & $(0.18)$ & $(0.33)$ & $(0.14)$ & $(0.47)$ \\
$\rho$ & $0.82 * *$ & $0.77 * *$ & $0.73 * *$ & $0.66 * *$ & $0.85 * *$ \\
& $(0.04)$ & $(0.04)$ & $(0.08)$ & $(0.07)$ & $0.07)$ \\
Adjusted r-squared & 0.94 & 0.97 & 0.95 & 0.98 & 0.90 \\
Standard error of & & & & & \\
the regression & 0.77 & 0.34 & 0.52 & 0.30 & 0.40 \\
\hline
\end{tabular}

Notes: Heteroskedasticity and autocorrelation robust standard errors in parenthesis. ** denotes statistically significant at the 5 percent level; * denotes statistically significant at the 10 percent level.

Source: Authors' calculations.

\footnotetext{
${ }^{20}$ GMM estimation gives similar results. For Brazil, a more backward-looking specification with current inflation is used as it yields more stable coefficients.
} 


\section{Output Gap Revisions and Policy Revisions}

The monetary policy reaction functions estimated above can be combined with revised real GDP data to calculate the extent to which policy formulated in real time deviated from the ideal policy calculated ex post using revised data. The ideal policy calculated ex post could not have been implemented in real time since the data informing the policy were not available. The purpose of the calculation is to demonstrate the potential inaccuracy of a policy rule relying heavily on an estimated output gap that is susceptible to large revisions.

Figure 8 uses the coefficients on the output gap estimated in Table 6 to calculate the policy deviation owing to output gap revisions. The deviation is calculated as the actual policy interest rate minus the rate that would have been prescribed using the coefficients in Table 6 and the estimated output gap calculated using real GDP data and expectations available through the second quarter of 2014. A positive (negative) value thus implies that actual policy was tighter (looser) than revised data would recommend.

Following directly from the magnitude of output gap revisions presented in earlier sections, the policy deviations generated by these revisions are substantial. Deviations of over 100 basis points occur in multiple episodes across all countries. Some episodes are shortlived, but there are several instances in which these deviations last for over a year, reflecting the tendency for output gap revisions to display a high degree of persistence.

Revisions to a policy rule based on economic conditions in the current quarter are substantial, but a central bank may react to broad trends in economic activity spanning multiple periods. Averaging across periods may help to reduce the noise-to-signal ratio in the data. To evaluate whether this kind of policy rule would generate policy prescriptions that are less susceptible to revision, we estimate reaction functions using a three-quarter moving average of the output gap and calculate the policy deviations owing to output gap revisions. ${ }^{21}$ The results are not shown since the deviations were quite similar in magnitude to those in Figure 7, only displaying more persistence. This is in line with the behavior of the smoothed output gaps, whose revisions are more persistent but similar in magnitude to the non-smoothed gaps.

\section{E. Output Gap Revisions and Inflation}

The previous section showed that prescriptions from policy rules relying on the output gap are subject to substantial revisions. However, under inflation targeting these revisions only pose a problem to the extent that they contain information about inflation that is not otherwise accounted for in the central bank's reaction function.

If output gap revisions are not related to deviations of inflation from the target, this demonstrates that the central bank is able to use other information to assess output relative to

\footnotetext{
${ }^{21}$ In this rule, the central bank responds to an average of the output gap in the previous two quarters and market expectations of the output gap in the current quarter.
} 
Figure 8. Policy Deviations Owing to Output Gap Revisions

(Actual interest rate minus revised prescription from reaction function, in percentage points)
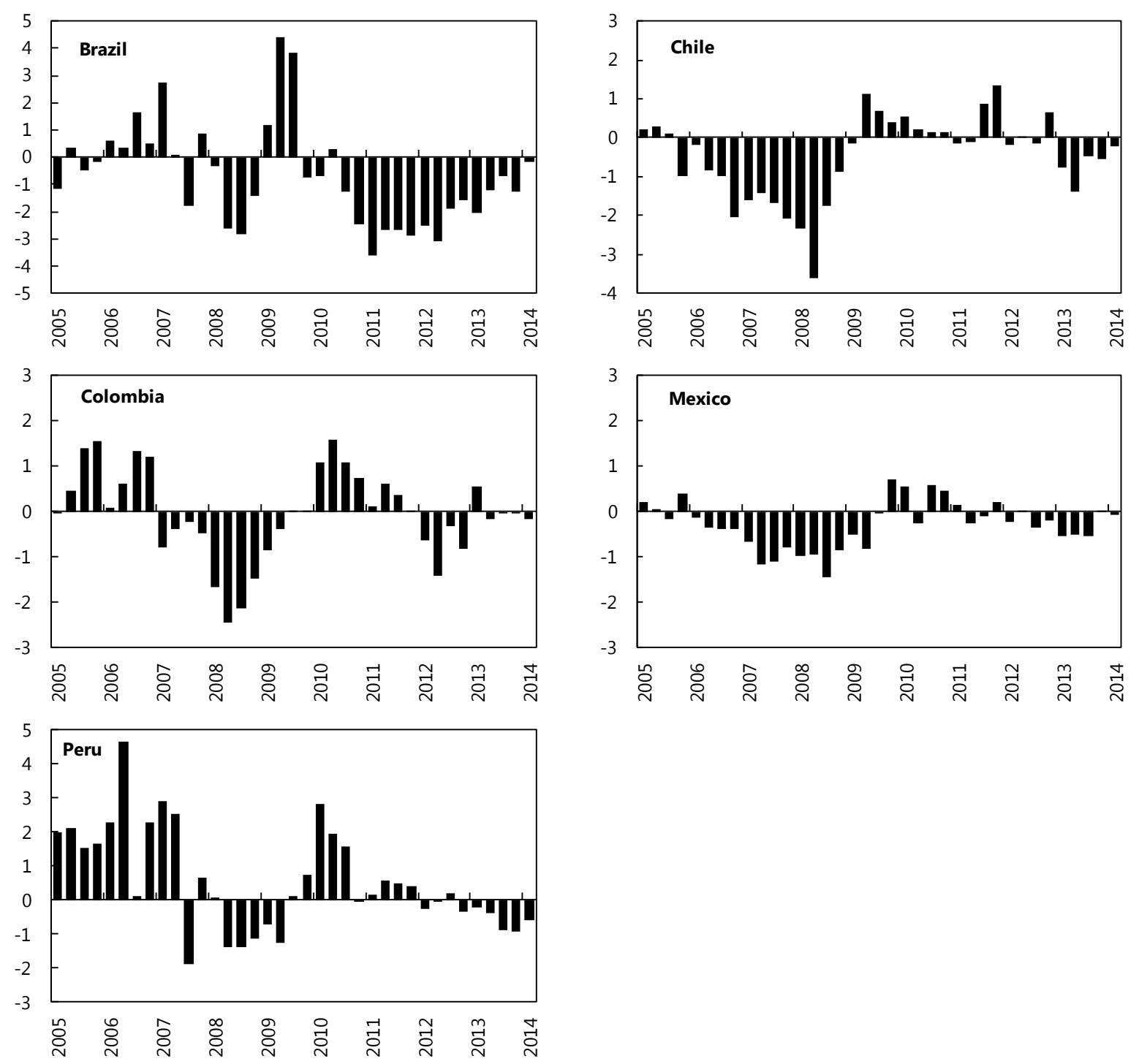

Source: Authors' calculations.

potential and adjust accordingly to keep inflation on target. However, if output gap revisions are related to deviations of inflation from the target, this suggests that the information regarding inflation that these revisions contain is not found in other data that the central bank has access to at the time of its policy decisions.

To evaluate the informational content of output gap revisions for inflation, we run regressions for either headline or core inflation on either the initial estimates of the output gap or revisions to the gap (the final estimate minus the initial one), using equations of the following form:

$\pi_{t}=\alpha+\sum_{i=0}^{4} \beta_{i} \bar{y}_{i}+\varepsilon$ 
where $\bar{y}_{i}$ is either the initial estimate of the output gap or the revision. It has already been established that initial estimates of the output gap tend to be measured with error. In regressions using the initial estimates, this measurement error would bias the $\beta_{i}$ coefficients in equation (8) toward zero.

Given transmission lags from the output gap to inflation, we include four lags. We run a separate set of regressions without the contemporaneous term for the output gap to ensure that simultaneity between output and inflation (owing to supply shocks, for example) does not drive the results.

Given the persistence of estimated output gaps and their revisions, the question of interest is whether the output gap terms in equation (8) are jointly significant for inflation. We perform Wald $F$-tests (robust to heteroskedasticity and autocorrelation) to measure the joint significance of the output gap terms in the equation.

Table 8 shows the results of the $F$-tests and underlines two key findings: i) Initial estimates of the output gap are measured with such error that other than in Colombia they are not informative about the future direction of inflation; and ii) Output gap revisions are highly informative about future inflation in all countries. ${ }^{22}$ They explain 40 to 50 percent of the variation in inflation, on average. Exclusion of the contemporaneous output gap term or use of core inflation instead of headline inflation does not overturn these results.

Table 8. Output Gap as a Predictor of Inflation

(Probabilities of Wald $F$-tests measuring the joint significance of the output gap terms on inflation)

\begin{tabular}{|c|c|c|c|c|c|c|c|c|}
\hline & \multicolumn{4}{|c|}{ Initial estimate of the output gap } & \multicolumn{4}{|c|}{ Revision to output gap } \\
\hline & \multicolumn{2}{|c|}{ Headline } & \multicolumn{2}{|c|}{ Core } & \multicolumn{2}{|c|}{ Headline } & \multicolumn{2}{|c|}{ Core } \\
\hline & Lags 0-4 & Lags 1-4 & Lags 0-4 & Lags 1-4 & Lags 0-4 & Lags 1-4 & Lags 0-4 & Lags 1-4 \\
\hline Brazil & & & & & $* *$ & $* *$ & & $*$ \\
\hline Chile & & & & & $* *$ & $* *$ & $* *$ & $* *$ \\
\hline Colombia & $* *$ & $* *$ & $* *$ & $* *$ & $* *$ & $* *$ & $* *$ & $*$ \\
\hline Mexico & & & $*$ & & $* *$ & $* *$ & $* *$ & $* *$ \\
\hline Peru & & & & & $* *$ & $* *$ & $* *$ & $* *$ \\
\hline
\end{tabular}

Notes: $* *$ denotes statistically significant at the 5 percent level; * denotes statistically significant at the 10 percent level. Shaded cells denote statistically significant relationships of the wrong sign.

Source: Authors' calculations.

These findings suggest that noisy initial estimates of the output gap surround with uncertainty the formulation of appropriate countercyclical monetary policy. They also show that information that is important for inflation is not taken account in real time, precisely because the level of economic activity relative to its potential is not known with much

${ }^{22}$ The findings are the same when using the final estimate of the output gap rather than just the revision. 
certainty until long after policy decisions have been made. This underscores a key weakness of monetary policy rules relying on real-time assessments of the cyclical position of the economy.

\section{SUMmary AND CONCLUSIONS}

This paper illustrates the wide range of uncertainty that is often associated with country desks' output gap assessments. We find that initial assessments of an economy's cyclical position overestimate the amount of slack in the economy, and that revisions are persistent, especially during recessions. The paper also shows that only a small share of this uncertainty can be explained by factors known to policymakers in real time, and that trying to explain whether the initial estimate of the output gap will change sign is equally challenging. In particular, we find that output gap revisions are positively associated with the absolute value of the initial estimate of the output gap, and similarly, that real GDP growth surprises tend to make subsequent output gap revisions larger. Evidence on the effects of macroeconomic uncertainty on output gap revisions is mixed, while quality of data is a statistically significant determinant of the revisions. In addition, countries with inflation targeting regimes have lower output gap revisions.

Output gap data and revisions can be used to construct confidence intervals around any initial or revised output gap estimate. The width of the confidence interval will vary by country, and by the vintage of the revision, with a wider confidence interval for an initial estimate than for a revised estimate. We find that, at the time of the initial estimate confidence intervals are usually so large as to span positive and negative values for the output gap. In other words, only in rare cases is there a high degree of certainty about whether policy should be contractionary, neutral, or expansionary. These results underscore the challenges policymakers face when using policy rules that depend on an assessment of the economy's cyclical position to set the value for a policy instrument.

The paper analyzes the implications of output gap uncertainty in the case of five Latin American economies (Brazil, Chile, Colombia, Mexico and Peru) that adopted inflation targeting as their monetary policy framework between 1999 and 2002. Assessing the economy's actual level of output relative to its potential is then a key policy input for these countries, as the degree of spare capacity is typically an important predictor of future inflation. We find that monetary policy reaction functions using revised (more accurate) real GDP data result, in many cases, in values for the policy instrument that are significantly different than those prescribed using initial estimates of the output gap. In addition, revised estimates of the output gap are positively and significantly correlated with inflation, suggesting that this information is not accounted for in real-time policy decisions.

These findings suggest that information that is important for inflation is not taken into account by central banks in their policy decisions. This occurs, at least in part, because the level of economic activity with respect to its potential is not known with much certainty until 
long after policy decisions have been made. The difficulty in distinguishing between cyclical fluctuations and shifts in the trend rate of growth underscores a key weakness of monetary policy rules relying on real-time assessments of the cyclical position of the economy, even when policymakers consult a large set of indicators. 
Appendix I. Data

Table A1. Countries Included in the Analysis

\begin{tabular}{|c|c|c|c|c|c|}
\hline \multicolumn{6}{|c|}{ Advanced economies } \\
\hline $\begin{array}{l}\text { Australia * } \\
\text { Austria * + } \\
\text { Belgium * }+ \\
\text { Canada * + }\end{array}$ & $\begin{array}{l}\text { Denmark * } \\
\text { Finland * } \\
\text { France * }{ }^{*} \\
\text { Germany * }\end{array}$ & $\begin{array}{l}\text { Greece * + } \\
\text { Iceland * + } \\
\text { Ireland * + } \\
\text { Italy * + }\end{array}$ & $\begin{array}{l}\text { Japan * }+ \\
\text { Luxembourg * } \\
\text { Netherlands * + } \\
\text { New Zealand * + }\end{array}$ & $\begin{array}{l}\text { Norway * }+ \\
\text { Portugal * }+ \\
\text { Spain * }+ \\
\text { Sweden * }\end{array}$ & $\begin{array}{l}\text { Switzerland * + } \\
\text { Turkey + } \\
\text { United Kingdom * + } \\
\text { United States * + }\end{array}$ \\
\hline \multicolumn{6}{|c|}{ Emerging economies } \\
\hline $\begin{array}{l}\text { Albania } \\
\text { Algeria } \\
\text { Angola } \\
\text { Antigua and Barbuda } \\
\text { Argentina } \\
\text { Armenia } \\
\text { Azerbaijan, Rep. of } \\
\text { Bahamas, The } \\
\text { Bahrain, Kingdom of } \\
\text { Barbados } \\
\text { Belarus } \\
\text { Belize } \\
\text { Bhutan } \\
\text { Bolivia } \\
\text { Bosnia \& Herzegovina } \\
\text { Botswana } \\
\text { Brazil } \\
\text { Brunei Darussalam } \\
\text { Bulgaria } \\
\text { Cameroon }\end{array}$ & $\begin{array}{l}\text { Cape Verde } \\
\text { Chile } \\
\text { China,P.R.: Mainland } \\
\text { China,P.R.:Hong Kong * } \\
\text { Colombia } \\
\text { Congo, Republic of } \\
\text { Costa Rica } \\
\text { Croatia } \\
\text { Cyprus * } \\
\text { Czech Republic + } \\
\text { Côte d'Ivoire } \\
\text { Djibouti } \\
\text { Dominica } \\
\text { Dominican Republic } \\
\text { Ecuador } \\
\text { Egypt } \\
\text { El Salvador } \\
\text { Equatorial Guinea } \\
\text { Estonia } \\
\text { Fiji }\end{array}$ & $\begin{array}{l}\text { Gabon } \\
\text { Georgia } \\
\text { Ghana } \\
\text { Grenada } \\
\text { Guatemala } \\
\text { Guinea } \\
\text { Guyana } \\
\text { Honduras } \\
\text { Hungary + } \\
\text { India } \\
\text { Indonesia } \\
\text { Iran, I.R. of } \\
\text { Israel * } \\
\text { Jamaica } \\
\text { Jordan } \\
\text { Kazakhstan } \\
\text { Kiribati } \\
\text { Korea, Republic of * } \\
\text { Kuwait } \\
\text { Lao People's Dem.Rep }\end{array}$ & $\begin{array}{l}\text { Latvia } \\
\text { Lebanon } \\
\text { Lesotho } \\
\text { Libya } \\
\text { Lithuania } \\
\text { Macedonia, FYR } \\
\text { Malaysia } \\
\text { Maldives } \\
\text { Mauritania } \\
\text { Mauritius } \\
\text { Mexico } \\
\text { Moldova } \\
\text { Mongolia } \\
\text { Morocco } \\
\text { Namibia } \\
\text { Nicaragua } \\
\text { Nigeria } \\
\text { Oman } \\
\text { Pakistan } \\
\text { Panama }\end{array}$ & $\begin{array}{l}\text { Papua New Guinea } \\
\text { Paraguay } \\
\text { Peru } \\
\text { Philippines } \\
\text { Poland + } \\
\text { Qatar } \\
\text { Romania } \\
\text { Russian Federation } \\
\text { Samoa } \\
\text { Saudi Arabia } \\
\text { Senegal } \\
\text { Seychelles } \\
\text { Singapore * } \\
\text { Slovak Republic } \\
\text { Slovenia * } \\
\text { Solomon Islands } \\
\text { South Africa } \\
\text { Sri Lanka } \\
\text { St. Kitts and Nevis } \\
\text { St. Lucia }\end{array}$ & $\begin{array}{l}\text { St. Vincent \& Grens. } \\
\text { Sudan } \\
\text { Suriname } \\
\text { Swaziland } \\
\text { São Tomé \& Príncipe } \\
\text { Thailand } \\
\text { Tonga } \\
\text { Trinidad and Tobago } \\
\text { Tunisia } \\
\text { Turkmenistan } \\
\text { Ukraine } \\
\text { United Arab Emirates } \\
\text { Uruguay } \\
\text { Uzbekistan } \\
\text { Vanuatu } \\
\text { Venezuela, Rep. Bol. } \\
\text { Vietnam } \\
\text { Yemen, Republic of } \\
\text { Zambia }\end{array}$ \\
\hline \multicolumn{6}{|c|}{ Low income countries } \\
\hline $\begin{array}{l}\text { Bangladesh } \\
\text { Benin } \\
\text { Burkina Faso } \\
\text { Burundi } \\
\text { Cambodia } \\
\end{array}$ & $\begin{array}{l}\text { Central African Rep. } \\
\text { Chad } \\
\text { Comoros } \\
\text { Congo, Dem. Rep. of } \\
\text { Eritrea } \\
\end{array}$ & $\begin{array}{l}\text { Ethiopia } \\
\text { Gambia, The } \\
\text { Guinea-Bissau } \\
\text { Haiti } \\
\text { Kenya }\end{array}$ & $\begin{array}{l}\text { Kyrgyz Republic } \\
\text { Madagascar } \\
\text { Malawi } \\
\text { Mali } \\
\text { Mozambique } \\
\end{array}$ & $\begin{array}{l}\text { Nepal } \\
\text { Niger } \\
\text { Rwanda } \\
\text { Sierra Leone } \\
\text { Tajikistan } \\
\end{array}$ & $\begin{array}{l}\text { Tanzania } \\
\text { Togo } \\
\text { Uganda }\end{array}$ \\
\hline
\end{tabular}

Notes: Countries with an asterisk were included in WEO data regressions and those with a plus sign were included in OECD data regressions. Advanced

economies correspond to OECD member economies since 1990. Low income countries correspond to all countries with a GNI per capita of $\$ 1,045$ or less in

2012. Emerging economies are all remaining economies in the sample. 


\section{Table A2. Description and Sources of Variables}

\begin{tabular}{|c|c|c|c|}
\hline Variable & Source & $\begin{array}{l}\text { Time of } \\
\text { measurement }\end{array}$ & Definition \\
\hline \multicolumn{4}{|c|}{ Annual data } \\
\hline Abs. output gap revision & $\begin{array}{l}\text { IMF WEO; Authors' } \\
\text { calculations }\end{array}$ & $\mathrm{t}+7 ; \mathrm{t}+1$ & $\begin{array}{l}\text { Absolute value of the cumulative output gap revision of time } t \text {, measured between time } \\
t+1 \text { and } t+7 \text { in percent of potential GDP. Output gap deviations are calculated using } \\
\text { HP filtered WEO data, observed WEO data, or observed OECD data. }\end{array}$ \\
\hline Abs. output gap (HP filtered WEO data) & $\begin{array}{l}\text { IMF WEO; Authors' } \\
\text { calculations }\end{array}$ & $t+1$ & $\begin{array}{l}\text { Absolute value of the initial output gap in time } t \text {, in percent of potential GDP. Potential } \\
\text { GDP is calculated using a Hodrick-Prescott filter on real GDP data from each fall } \\
\text { WEO vintage between } 1990 \text { and } 2014 \text {. The smoothing parameter lambda is set to } \\
100 \text { to replicate WEO output gap estimates as close as possible. To ensure accurate } \\
\text { smoothing, we run the HP filter on each country-vintage if there is available data from } \\
1980 \text { onwards and at least } 15 \text { consecutive observations. WEO data for forecasts five } \\
\text { years ahead is included in the HP filter to avoid endpoint bias. }\end{array}$ \\
\hline Abs. output gap (observed WEO/OECD estimate) & IMF WEO; OECD & $t+1$ & $\begin{array}{l}\text { Absolute value of the initial output gap in time } t \text {, in percent of potential GDP. } \\
\text { Estimates are obtained from the IMF WEO or the OECD economic outlook. }\end{array}$ \\
\hline Abs. real GDP growth surprise & $\begin{array}{l}\text { IMF WEO; OECD; Authors' } \\
\text { calculations }\end{array}$ & $t+1$ & $\begin{array}{l}\text { Difference between real GDP growth and the mean growth of the last } 10 \text { years, in } \\
\text { absolute terms. Data are calculated using observed WEO data or observed OECD } \\
\text { data. }\end{array}$ \\
\hline Abs. world real GDP growth surprise & $\begin{array}{l}\text { IMF WEO; OECD; Authors' } \\
\text { calculations }\end{array}$ & $\mathrm{t}+1$ & $\begin{array}{l}\text { Difference between real world GDP growth and the mean world growth of the last } 10 \\
\text { years, in absolute terms. Data are calculated using observed WEO data or observed } \\
\text { OECD data. }\end{array}$ \\
\hline Real GDP growth SD & $\begin{array}{l}\text { IMF WEO; OECD; Authors' } \\
\text { calculations }\end{array}$ & $\mathrm{t}+1$ & $\begin{array}{l}\text { Standard deviation of domestic real GDP growth over the last } 10 \text { years. Data are } \\
\text { calculated using observed WEO data or observed OECD data. }\end{array}$ \\
\hline Rents/GDP & $\begin{array}{l}\text { World Bank Worldwide } \\
\text { Development Indicators }\end{array}$ & & $\begin{array}{l}\text { Total natural resources rents, in percent of GDP. Defined as the sum of oil, natural } \\
\text { gas, coal, mineral, and forest rents. }\end{array}$ \\
\hline Inflation & $\begin{array}{l}\text { IMF WEO; Authors' } \\
\text { calculations }\end{array}$ & & $\begin{array}{l}\text { Bounded CPI-based inflation indicator, derived from the inter-temporal consumption } \\
\text { optimization of consumer in a discrete time framework. The indicator is calculated as } \\
\text { the inflation rate divided by one plus the rate of inflation - expressed in decimals rather } \\
\text { than percent - such that the indicator is always bounded between zero and one. }\end{array}$ \\
\hline Inflation targeting & IMF Finance \& Development & & Dummy variable for an inflation targeting framework; $1=$ yes, $0=$ no. \\
\hline Cyclical fiscal rules & IMF Fiscal Rules Dataset & & $\begin{array}{l}\text { Dummy variable for a national or supranational stabilization fiscal rule; } 1=y e s, 0= \\
\text { no. }\end{array}$ \\
\hline OECD & Authors' calculations & & Dummy variable for OECD member economy as of $1990 ; 1=$ yes, $0=$ no. \\
\hline LIC & IMF; Authors' calculations & & Dummy variable for low income country as classified by the IMF; $1=$ yes, $0=$ no. \\
\hline Small economy & Authors' calculations & & $\begin{array}{l}\text { Dummy variable for small economy; } 1=y e s, 0=\text { no. Defined as economies with } \\
\text { average populations below the } 10 \text { th percentile of the population distribution. }\end{array}$ \\
\hline Time index & Authors' calculations & & $\begin{array}{l}\text { Linear trend accounting for the learning process of estimating the output gap across } \\
\text { the sample period. }\end{array}$ \\
\hline GDDS & IMF; Authors' calculations & & $\begin{array}{l}\text { Dummy variable for IMF member using the General Data Dissemination System; } 1= \\
\text { yes, } 0=\text { no. }\end{array}$ \\
\hline SDDS & IMF; Authors' calculations & & $\begin{array}{l}\text { Dummy variable for IMF member using the Special Data Dissemination System; } 1= \\
\text { yes, } 0=\text { no. }\end{array}$ \\
\hline Conflict & $\begin{array}{l}\text { World Bank Worldwide } \\
\text { Development Indicators }\end{array}$ & & $\begin{array}{l}\text { Dummy variable based on battle-related deaths; } 1=\text { more than } 1,000 \text { deaths, } 0=\text { all } \\
\text { other cases. }\end{array}$ \\
\hline Bureaucratic quality & $\begin{array}{l}\text { International Country Risk } \\
\text { Guide }\end{array}$ & & $\begin{array}{l}\text { Ranking of quality of bureaucracy and institutional strength. Higher ranking } \\
\text { corresponds to stronger bureaucratic institutions. }\end{array}$ \\
\hline Control of corruptoion & $\begin{array}{l}\text { International Country Risk } \\
\text { Guide }\end{array}$ & & $\begin{array}{l}\text { Ranking of corruption within the political system. Higher ranking corresponds to less } \\
\text { corruption. }\end{array}$ \\
\hline Abs. average future real GDP growth differential & $\begin{array}{l}\text { IMF WEO; Authors' } \\
\text { calculations }\end{array}$ & $t+7$ & $\begin{array}{l}\text { Absolute value of the difference between the mean real GDP growth of the last five } \\
\text { years and the mean real GDP growth of the following five years. }\end{array}$ \\
\hline \multicolumn{4}{|c|}{ Quarterly data } \\
\hline Output gap (initial) & $\begin{array}{l}\text { National authorities; } \\
\text { Authors' calculations }\end{array}$ & $\mathrm{t}+1$ & $\begin{array}{l}\text { Value of the initial output gap in time t, in percent of potential GDP. Potential GDP is } \\
\text { calculated using a Hodrick-Prescott filter on real GDP data with a smoothing } \\
\text { parameter of } 400 \text {. To avoid endpoint bias in the HP filter, observed real GDP data is } \\
\text { spliced with real GDP growth expectatons data to extend the series past the endpoint } \\
\text { of actual data. }\end{array}$ \\
\hline Output gap (final) & $\begin{array}{l}\text { National authorities; } \\
\text { Authors' calculations }\end{array}$ & & $\begin{array}{l}\text { Constructed using the same method as the initial output gap, with data available } \\
\text { through } 2014 \text { Q2. }\end{array}$ \\
\hline Real GDP & National authorities & $t+1$ & Real GDP in local currency. \\
\hline Real GDP expectations & National authorities & $t+1$ & $\begin{array}{l}\text { Real GDP growth expectations of market participants surveyed by country central } \\
\text { banks, in percent. }\end{array}$ \\
\hline Headline inflation & National authorities & $t+1$ & Consumer price index, 12 month percent change \\
\hline Core inflation & National authorities & $t+1$ & Core consumer price index, 12 month percent change \\
\hline Inflation expectations & National authorities & $t+1$ & $\begin{array}{l}\text { Twelve-month ahead inflaton expectations of market participants surveyed by country } \\
\text { central banks, in percent. }\end{array}$ \\
\hline Policy rate & National authorities & $t+1$ & Nominal interest rate, in percent. \\
\hline
\end{tabular}




\section{References}

Congressional Budget Office, 2001, CBO's Method for Estimating Potential Output: An Update (Washington, D.C.).

Baxter, Marianne, and Robert G. King, 1999, "Measuring Business Cycles: Approximate Band-Pass Filters for Economic Time Series," The Review of Economics and Statistics, Vol. 81(4), pp. 575-593.

Dreher, Axel, Silvia Marchesi, and James R. Vreeland, 2008, "The Politics of IMF Forecasts," Public Choice, Vol. 137, pp. 145-171.

Ho, Giang, and Paolo Mauro, 2014, “Growth: Now and Forever?” IMF Working Paper 14/117 (Washington: International Monetary Fund).

International Monetary Fund, 2010, "World Economic Outlook. Recovery, Risk and Rebalancing," October 2010, Washington, D.C.

Ley, Eduardo, and Florian Misch, 2013, "Real-Time Macro Monitoring and Fiscal Policy," Policy Research Working Paper 6303 (Washington: World Bank). , 2014, "Output Data Revisions in Low-Income Countries," paper presented at the International Monetary Fund conference, "Macroeconomic Challenges Facing LowIncome Countries: New Perspectives," Washington, D.C., January.

Orphanides, Athanasios, 2001, "Monetary Policy Rules Based on Real-Time Data," The American Economic Review, Vol. 91, No. 4, pp. 964-985. , and Simon van Norden, 2002, "The Unreliability of Output Gap Estimates in Real Time," The Review of Economics and Statistics, Vol. 84, pp. 569-583.

, and John C. Williams, 2007, "Robust Monetary Policy with Imperfect Knowledge," Journal of Monetary Economics, Vol. 54, pp. 1406-1435.

Ravn, Morten O., and Uhlig, Harald, 2002, "On Adjusting the Hodrick-Prescott Filter for the Frequency of Observations," The Review of Economics and Statistics, Vol. 82, No. 2, pp. 371-375.

Roger, Scott, 2010, “Inflation Targeting Turns 20,” Finance \& Development, Vol. 47 (March), pp. 46-49.

Timmermann, Allan, 2007, "An Evaluation of the World Economic Outlook Forecasts," IMF Staff Papers, Vol. 54, No. 1, pp. 1-33.

Woodford, Michael, 1999, "Optimal Monetary Policy Inertia," The Manchester School Supplement, pp. 1-35. 